\title{
Measuring labour market segmentation for a comparative analysis among countries
}

\section{Pedro López-Roldán ${ }^{1}\left(\mathbb{D} \cdot\right.$ Sandra Fachelli ${ }^{2,3}$ (D)}

Accepted: 1 November 2020

(c) Springer Nature B.V. 2021

\footnotetext{
1 Departament of Sociology, Sociological Research Centre on Everyday Life and Work, Institute for Labour Studies, Universitat Autònoma de Barcelona, Barcelona, Spain

${ }^{2}$ Department of Sociology, Universidad Pablo de Olavide, Sevilla.

${ }^{3}$ Grup de Recerca en Educació i Treball, Universitat Autònoma de Barcelona, Barcelona, Spain
} 


\section{UAB \\ Universitat Autònoma de Barcelona}

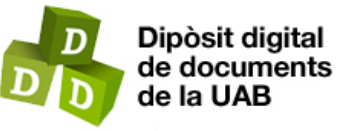

This is the accepted version of the journal article:

López-Roldán, Pedro; Fachelli, Sandra. «Measuring labour market segmentation for a comparative analysis among countries». Social indicators research, Vol. 154, núm. 3 (2021), p. 857-892. DOI 10.1007/s11205-020-02550-1

This version is available at https://ddd.uab.cat/record/236341

under the terms of the C) ${ }_{\text {COPYRIGHT license }}^{\text {IN }}$ 


\begin{abstract}
This article raises one main question in a comparative analytical exercise between two countries in different continents, Spain and Argentina. To what extent does labour market segmentation generate similar dynamics of structuring of labour inequalities in two countries with different socio-economic contexts and social models, and which aspects are specific to each country? The article is the first analytical work aimed at comparing European and Latin American countries from the theoretical perspective of labour market segmentation. We set two main objectives. The first was to construct an analysis model to study inequalities in the labour market in comparative terms between Europe and Latin America, taking as a reference Spain and Argentina. To this end, demand and supply variables were combined from an employment perspective. We sought to corroborate the general hypothesis that there is no single labour market that adjusts supply and demand, but that several segments can be expected to structure hierarchical positions in the labour market in line with specific labour supply profiles. We expected to obtain a high correspondence between the employment segments of the two countries, despite the contextual and socio-historical differences. The second objective was to propose a methodology to obtain two synthetic measures of labour market segmentation: first, a categorical measurement through a typology constructed from hierarchical positions and profiles using multivariate techniques (combining multiple correspondence factor analysis and cluster analysis); and second, a continuous measurement based on the results of factor analysis, resulting in a composite indicator of labour inequality.
\end{abstract}

Keywords: Labour Inequality, Labour Market Segmentation, Typology, Composite Indicator

\title{
1. Introduction
}

This article raises one main question in a comparative analytical exercise between two countries in different continents, Spain and Argentina. To what extent does labour market segmentation generate similar dynamics of structuring of labour inequalities in two countries with different socio-economic contexts and social models, and which aspects are specific to each country? The article is the first analytical work aimed at comparing European and Latin American countries from the theoretical perspective of labour market segmentation.

Using different theoretical foundations and proposals for operationalization, the segmentation perspective has proposed a structural explanation of how the labour market works. It uses a multidimensional approach, taking into account supply and demand factors, in addition to institutional factors and the socio-economic and developmental context of each country, which interact and affect the configuration of various segments of work and employment as an expression of inequalities in the labour market.

We present the results of a study that we carried out in the context of an international project of INCASI. ${ }^{4}$

We set two main objectives. The first was to construct an analysis model to study inequalities in the labour market in comparative terms between Europe and Latin America, taking as a reference Spain and Argentina. To this end, demand and supply variables were combined from an employment perspective. We sought to corroborate the general hypothesis that there is no single labour market that

\footnotetext{
${ }^{4}$ INCASI aims to create and consolidate a network of research and training between Europe and Latin America. To this end, we carried out the project Global trends in social inequalities in Europe and Latin America and exploring innovative ways to reduce them through life, occupational and educational trajectories research to face uncertainty from January 2016 to December 2019 . For more information, see the website http://incasi.uab.es/en.
} 
adjusts supply and demand, but that several segments can be expected to structure hierarchical positions in the labour market in line with specific labour supply profiles. We expected to obtain a high correspondence between the employment segments of the two countries, despite the contextual and socio-historical differences.

The second objective was to propose a methodology to obtain two synthetic measures of labour market segmentation: first, a categorical measurement through a typology constructed from hierarchical positions and profiles using multivariate techniques (combining multiple correspondence factor analysis and cluster analysis); and second, a continuous measurement based on the results of factor analysis, resulting in a composite indicator of labour inequality.

The article is divided into four sections. In Section 2, we present the theoretical perspective of labour market segmentation and the contextual elements of each country, and we construct an analysis model that is operationalized by means of multiple variables obtained from the labour force surveys of each country. In Section 3, we analyse the results for both countries with regard to the hypothesis and the segmentation measures used. Finally, Section 4 presents a discussion of the results and the main conclusions.

\section{Theoretical background and analysis model}

In order to account for the functioning of the labour market and the inequalities existing in it, we adopted the theoretical perspective of labour market segmentation. In contrast to the traditional postulates of neoclassical economics, the unic market model adjusted in prices and quantities according to the logic of free competition and the theory of human capital is questioned to highlight the fragmented functioning of the capitalist labour market. From the point of view of segmentation, the division between atypical jobs and standard jobs is a fundamental dimension to determine the stratification implied by the segments of the labor market, but it is insufficient to account for the complexity of a phenomenon that goes beyond a vision of insiders and outsiders and the wage gap that it entails (Dickens and Lang, 1988). In addition, it should be put in relationship, in a certain regulatory framework more or less inclined, with labour management practices of employers (Banyuls et al., 2009), in particular, with the policy of outsourcing of companies (Recio, 1988). Likewise, the activity sector, the size of the company or the bargaining power of the workers are important explanatory variables, as well as the characteristics of the productive structure in which the dynamics of the labor market occur (Fina and Toharia , 1987; Banyuls and Recio, 2017). We consider that there is no single labour market that adjusts supply and demand but rather various segments that follow specific operating rules. We postulate that the main explanatory factor of segmentation dynamics is on the demand side. Business strategies for the organization of production and work through policies of flexibility, outsourcing and subcontracting (Miguélez, 2004), seeking to maximize profits by minimizing costs and controlling the workforce, create unequal conditions and employment opportunities for the wage-earning population. In addition, the inequalities are reproduced and shaped in interaction with the supply side. Social characteristics of hired persons such as gender, age, immigrant origin, race and educational level are unevenly distributed and intersect according to the interests of employers' organizations to give rise to segmented jobs.

The segmentationist literature has identified these jobs in terms of the duality of the labour market, differentiating the primary segment from the secondary segment according to a hierarchy of working conditions and employment quality, as well as differentiated social profiles. This has been expressed in general terms in numerous contributions since the 1970s, including the works of Doeringer and Piore (1971), Rubery (1978), Gordon, Edwards and Reich (1982) Wilkinson (1981), Craig et al. (1982), Recio 
(1991), Grimshaw and Rubery (2005), Rubery (2005, 2007), Gibert (2011) and López-Roldán y Fachelli (2019).

This theoretical perspective is reflected and expanded in the proposal for renewal made by Grimshaw et al. (2017). Adopting a multidimensional perspective of factors that explain the functioning of the labour market and the generation of labour inequalities, this proposal for renewal follows the intellectual contributions of Jill Rubery and the Cambridge School, as well as the international Working Party on Labour Market Segmentation network. It proposes to jointly articulate three theoretical traditions to account for inequalities in work and employment: the approaches of labour market segmentation, comparative institutionalism and feminist socioeconomics.

We also orient our theoretical position in this direction. Figure 1 is a schematic representation of the general model that we propose. In addition to the factors related to supply and demand, we must consider the institutional aspects that affect the labour market, including the strategies of the actors within the regulatory and collective bargaining framework, the model of social and welfare policies and the sexual division of labour, in addition to contextual elements of the national productive structures (structural heterogeneity), the global economy and economic cycles.

Figure 1. Labour market segmentation. Analysis model

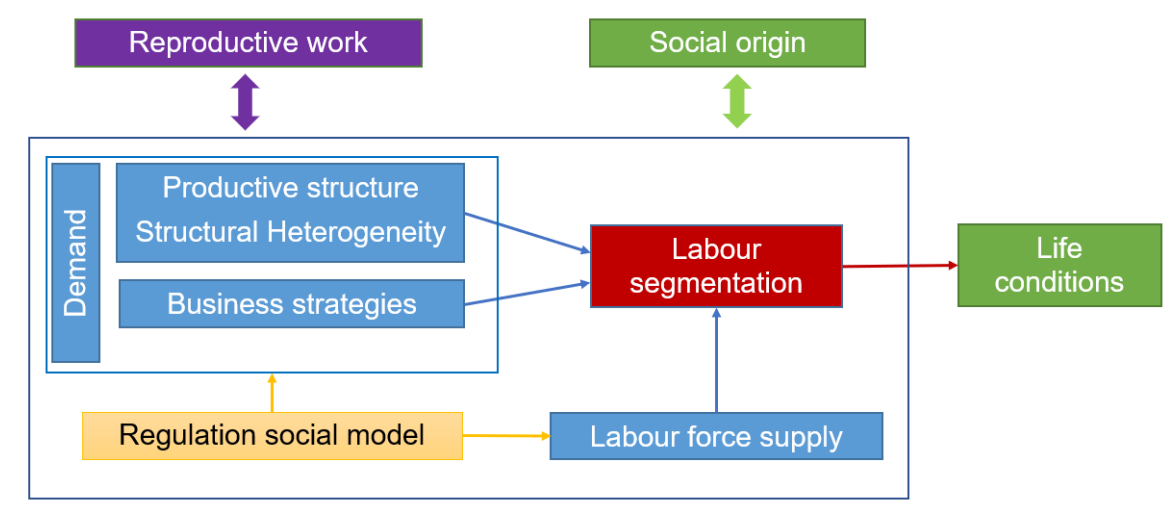

The dynamics of functioning of the labour market interact with the initial conditions of reproduction and social inequality, particularly in the sexual division of productive and reproductive work, and consequently lead to unequal living conditions for social groups.

From this theoretical perspective, we propose a general typological hypothesis that we will analyse below for the compared cases of Spain and Argentina. The structure of the labour market is conceived in terms of employment segments that divide the labour market into hierarchical positions as a result of the interaction of supply and demand factors and the institutional context and productive structure in which they occur. In dual terms, segmentation is expressed in the differentiation of a primary segment of stable, high-quality jobs with medium and high skill levels and a secondary segment of job insecurity and low skill levels. This fundamental division also involves internal differences in working conditions. The primary segment contains a higher subsegment with high occupational levels and better employment conditions and a lower subsegment with intermediate skill levels, both of which enjoy job security. The secondary segment is also divided into precarious positions and extreme situations of employment marginalization. This demand-driven segmentation corresponds in turn to differentiated characteristics of the labour force in terms of gender, age, immigrant origin and level of education. This expected general typology, which expresses the inequality in the labour market, is also expected to be similar in Spain and Argentina. Therefore, despite the contextual and developmental differences between the two countries, we postulate that the particular mechanisms put in place in the two capitalist economies generate a similar structuring of inequality in the labour market. 


\subsection{The Spanish and Argentine contexts}

Of course, Spain and Argentina have different levels of development and socio-historical contexts that explain the characteristics of social inequalities, and of the labour market in particular. In this section we will briefly describe some of the characteristics specific to each context. However, our aim will be to show that, despite the institutional and socio-economic differences between the two countries, the structuring of inequalities follows common patterns of typification of inequality in the labour market.

Spain is well known as an extreme case in the European Union because of its high level of temporary recruitment and its high unemployment rate, which varies according to the economic cycle. The persistence of this situation is due to the regulatory framework, which involves higher dismissal costs for open-ended contracts than for temporary contracts, which are therefore used as a business strategy for adjusting workforces (Banyuls and Recio, 2017). The employment policies introduced to counteract these trends have been weak, and some policies have even promoted them, in a general trend towards deregulation and individualization of labour relations (Alós, Beneyto and Jódar 2017). In fact, in line with the same trend in the rest of Europe, political reforms have sought flexibility in the labour market, finding in temporary or atypical recruitment a clear path of action even outside the sectors of low productivity and low-quality occupations (Molina y López-Roldán, 2015). These features are typical of the Spanish employment model, which is identified as Mediterranean neoliberal (Banyuls et al., 2009) and results from the convergence of various defining characteristics (López-Roldán y Fachelli, 2019): a productive structure of services with a predominance of small and medium-sized enterprises characterized by intensive use of labour, low skills and relatively low productivity; a production system separate from education; Taylorist business practices, with cost reduction strategies and external flexibility in labour management and little interest in training; an economy that includes undeclared work; a small number of large companies with a high technological level; and the fact that trade union action is limited to the primary area of large enterprises and cannot be exercised in the broad fabric of small enterprises, although trade unions enjoy great institutional recognition and legitimacy.

This situation has led to persistently high labour market segmentation and high levels of unemployment. To this must be added a weak welfare system. The Spanish state has improved its services and transfers since the establishment of democracy but, in comparison with the rest of Europe, the tax system and policies restricting the public sector have not yet resolved the inequalities that this employment model generates. The welfare system has to be supplemented by the solidarity of families, which is an obstacle to overcoming gender inequalities and applying an equitable social model of times and activities of daily life. The last forty years have seen profound and rapid changes that have led to the modernization of Spain, but persistent structural problems have reproduced social inequalities, particularly after the crisis, in a low-cost social model (Martín-Artiles, 2008).

Argentina shows some common elements with Spain, but has a different socio-economic reality aggravated by its situation as a peripheral country and its lower technological capacity. There are also major internal differences in its productive structure between sectors with high and low productivity, a situation described as Latin American structural heterogeneity (Prebisch, 1949; Pinto, 1970), which arises in contexts of macroeconomic instability and high inflation. The Argentine labour market has a highly regulated framework. Unlike Spain, Argentina has a temporary employment rate of only about $10 \%$, and this form of employment has shown a tendency to decrease as a result of regulatory changes aimed at discouraging its use that have been made since 2002. The Law on Labour Contracts establishes as a general rule that employment relationships are permanent, although there are fixed-term contracts that do not exceed five years and seasonal or temporary contracts for specific needs of companies, all with guarantees similar to those of open-ended contracts (Maurizio, 2016). However, there is a large 
amount of informal work of a salaried or self-employed nature that largely has the same effect of creating weak employment and poor working conditions. In Argentina, and in Latin America in general, there is thus a double segmentation: that arising from the division between open-ended and temporary work and that arising from the division between formal and informal work (ILO, 2016: 62).

If we analyse the two countries from the point of view of the social model, in which the labour relations model and the welfare model are interrelated to correct social inequalities through pre-distributive or post-distributive policies, we find that Spain and Argentina belong to two different models (MartínArtiles et al., 2021). ${ }^{5}$

Spain follows the model of mixed or semi-coordinated economies characteristic of Mediterranean countries, with mixed systems of collective bargaining including centralized collective bargaining at sectoral level, semi-decentralized regional bargaining and company-level bargaining. Trade unions have political influence and capacity for mobilization, but their representation is fragmented, as is that of the employers' organizations. Nevertheless, the coverage rate of collective bargaining in Spain is high, reaching 78\%. The high level of unemployment in Spain means that the amount spent on unemployment protection is higher than in other countries that follow this model. It takes up a large amount of the social spending, which is at an intermediate level in comparison with other EU countries. There is also some informal employment, which exacerbates the lack of social protection. In semicoordinated economies, the state plays an important role in correcting the dysfunctions of the coordination mechanisms, but the economic inequalities are greater than in the corporatist model of central and northern Europe.

The case of Argentina, on the other hand, follows the informal, uncoordinated economic model characteristic of Latin American countries. These countries have a low level of social spending, a very low proportion of workers with unemployment protection, high rates of economic inequality, both predistributive (generated in the labour market) and post-distributive (after social transfers), and a very high rate of informal employment, all of which hinder coordination between pre- and post-distributive policies. ${ }^{6}$ This profile entails a characterization of their economies as ones of structural heterogeneity or ones "with hierarchized labour markets" (Schneider 2009). Therefore, though it displays certain neocorporatist elements, with a system of sectoral collective bargaining, Argentina has high levels of inequality with its fragmented and stratified protection systems and encounters major obstacles to guaranteeing social pacts and wage coordination mechanisms. Its contributory social systems, its tax system and the coverage of unemployment protection are clearly insufficient to counteract social and labour market inequalities.

One of the most notable general features of Spain and Argentina is that they should be both considered as late industrializing countries, early-late in the case of Spain and late-late in the case of Argentina, according to the definition of Ishida and Miwa (2011). Both countries showed rapid industrial development and by 1975 they had experienced a significant reduction in the rural sector and agricultural production in favour of an industrial sector and, most notably, the service sector (Ishida and Miwa, 20011). Furthermore, the nature of the productive structure in both countries has been decisive: it is anchored in the reproduction of polarized sectors of production differentiated by high and low qualifications and good and bad working conditions.

The analysis of social inequalities in the labour market is not only the expression of circumscribed logics within the nation-state. Today, in globalised and highly interrelated societies, the dynamics of the world system and the international division of labour are creating relations of dependency and domination in

\footnotetext{
5 This concept resembles in part the broader one of varieties of capitalist systems based on the comparison of social institutions (Menz, 2008; Burroni, 2016).

${ }^{6}$ For further analysis of pre-distributive and post-distributive inequality, see Hacker (2011) and Zalakain and Barragué (2017).
} 
a competitive capitalist environment, generating divisions of world stratification between the centre and the periphery (and semiperiphery, Snyder \& Kick 1979; Arrighi 1985). In this sense, both countries can be considered as semiperipherical under the world-system theory, but with relative different positions taking into account level of inequalities and development (López-Roldán and Fachelli, 2021).

\subsection{Design of the analysis}

To contrast the typological hypothesis, we will operationalize our analysis model using a segmentation of employment approach (López-Roldán 1996b, López-Roldán et al. 1998, López-Roldán and Fachelli 2019) by comparing the cases of Spain and Argentina at one point in time. To achieve our comparative objective, we therefore analyse the employed population from the perspective of employment rather than work, i.e. based on the effects that arise in the labour sphere in terms of employment conditions. We understand that the segmentation processes include the convergence of institutional factors, the productive structure and labour supply and demand. We give demand a central role in segmentation mechanisms, so business policies in a context of production and work organisation are determinants of labour segmentation. In this context of companies, one must consider jobs to have effective functions and skills based on microsocial realities that respond differently to the needs of production and organization. The differentiated jobs are shaped according to their centrality for companies, skill levels, workforce control policies, the labour relations framework, the bargaining power of workers and trade unions, legislation, the sector, technology and the business cycle. These jobs are occupied with unequal employment conditions based on business strategies and involve varying levels of job security and quality. We therefore consider the aggregate macrosocial results that the segmentation dynamics of work expresses in terms of employment.

In our model we interrelate various dimensions of characterization of inequalities in employment, contrasting indicators from the point of view of labour supply and demand (Table 1). Both general dimensions can be analytically separated, but, as we state in our theoretical perspective, are strongly interrelationated. On the demand side, we consider four dimensions. First, job security is considered as a dimension of stability and precarity. Second, qualification differentiates occupational levels or formal occupational categories. To characterize it we use the International Standard Classification of Occupations (ISCO), which hierarchically measures the similar characteristics of the tasks and duties of jobs and the training necessary to perform them (competencies), together with the performance of supervisory functions. Third, the wage dimension is used as an economic indicator of employment quality. Finally, we take into account various characteristics of companies that contextualize the framework of social and organizational relationships within which jobs are given: the size, sector and ownership of companies. On the supply side, four dimensions of workforce characterization are considered that establish central factors of social inequality: gender, age, immigrant origin and education.

Our measurement methodology is based theoretically on a perspective that conceptually rationalizes and justifies the selection of the specific indicators of the multidimensional phenomenon of segmentation. However, we do not pre-configure the labour market segments. According to the theoretical perspective that guides this study, we expect to find different types of employment segment that correspond to the dynamics of structuring of social inequalities in the labour market in terms of primary and secondary segments, with possible internal divisions at lower or higher levels, as proposed in the literature. However, this theoretical typification is not imposed on the data. The segmentation measure was not constructed on the basis of a previous definition that establishes how the values of the variables chosen to account for each segment are combined. On the contrary, after establishing the attribute space (Barton 1985) with the variables that operationalize the segmentation model, the measure of the phenomenon is the result of applying the analysis techniques chosen for our purpose: the construction of a typology of employment segmentation. Thus, we follow a procedure in which the 
segments emerge from the analysis when we apply and validate, theoretically and empirically, a typology resulting from the combination of two multivariable analysis techniques (factor analysis and cluster analysis) that we discuss below. Thus, we obtain a first qualitative measure of segmentation. A second measure, based only on factor analysis, will lead us to obtain a quantitative measure of segmentation.

\section{Table 1. Dimensions and indicators of the employment segmentation model ${ }^{(*)}$}

\begin{tabular}{|c|c|}
\hline Dimension & Indicators/variables \\
\hline \multicolumn{2}{|l|}{ Labour market demand } \\
\hline 1. Security & $\begin{array}{c}\text { Type of contract and duration: Open-ended, }>6 \text { months, }<6 \text { months, } \\
\text { Informal }\end{array}$ \\
\hline & Type of workday: Full-time, Part-time \\
\hline & Seniority in the company: aggregation in months-years \\
\hline 2. Qualification & $\begin{array}{c}\text { Occupation: Managers and professionals, Technicians and administrative } \\
\text { staff, Skilled workers, Unskilled workers }\end{array}$ \\
\hline & $\begin{array}{c}\text { Supervision: } \begin{array}{c}\text { Management, Middle management, Person in charge, } \\
\text { Employee }\end{array}\end{array}$ \\
\hline 3. Salary & Salary deciles: Decile 1 to Decile 10 \\
\hline $\begin{array}{l}\text { 4. Characterization of } \\
\text { the company }\end{array}$ & $\begin{array}{l}\text { Sector: Primary, } 3 \text { Industries, Construction, Retail, } \\
\quad \text { Transportation-communications, Financial-professional, } \\
\quad \text { Public administration, Other services } \\
\text { Ownership of the company: Public, Private } \\
\text { Size: }<5,6-10,11-49,50-250,>250 \text { workers }\end{array}$ \\
\hline \multicolumn{2}{|l|}{ Labour market supply } \\
\hline 5. Gender & Sex: Male, Female \\
\hline 6. Age & Age: $16-24,25-29,30-34,35-39,40-44,45-49,50-54,55-59,>59$ years \\
\hline 7. Immigration & Nationality: National, Foreign \\
\hline 8. Education & Educational level: Primary, Secondary, University \\
\hline
\end{tabular}

(*) For some variables, the categorization will differ slightly depending on the source of information in each country (see Annex, Table A1).

We identify this general procedure as the construction of a structural and articulated typology (LópezRoldán, 1996a), a description that accounts for the purpose and content of the object of study and for the way in which the typology is constituted (see Figure 2). The structuring aims to order the social reality and position the different types of typology in an attribute space according to a theoretical perspective that accounts for and typifies a portion of social reality. It can thus be considered an analysis model that seeks a "structural explanation" (López-Roldán, 1996a; Fachelli et al., 2012). The articulation involves accounting for a research dynamic that articulates theory and empirics, where there are processes of interrelation between deduction/concretion and induction/abstraction.

Figure 2. A structured and articulated typology scheme

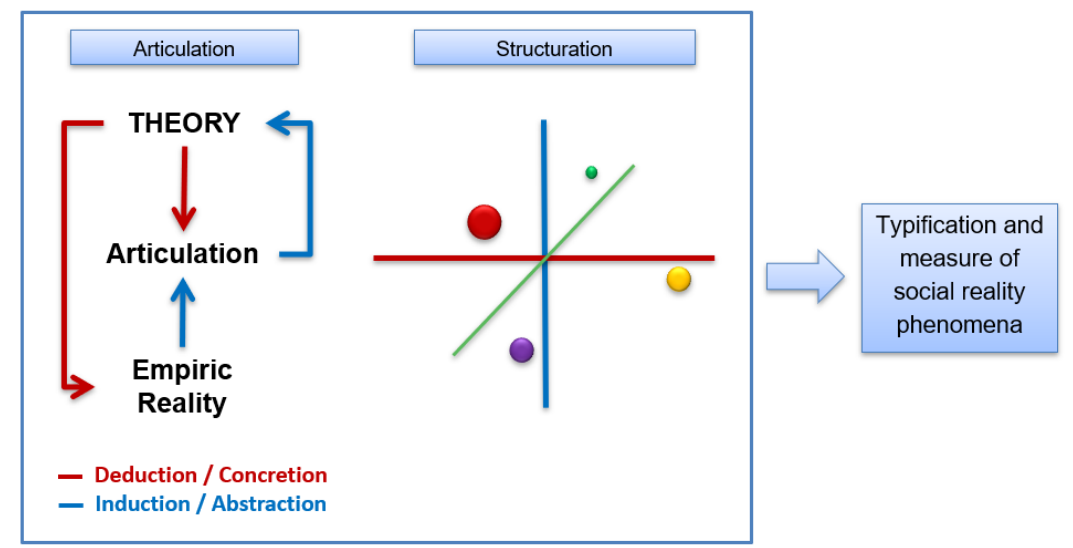




\section{Source: Author}

From the technical point of view of the analysis design, this approach is concretized in the sequential combination of multiple correspondence factor analysis (MCA) and cluster analysis (CLA). The process that we will follow can be represented schematically as shown in Figure 3. In the first stage, through the correspondence analysis we obtain the main factors structuring inequalities in the labour market. In the second stage, considering the factors obtained as classification criteria, we follow two procedures: on the one hand, we develop the empirical typology by applying a classification analysis technique in which we seek the greatest internal homogeneity within each type and therefore the greatest heterogeneity between types ( $3 \mathrm{~b}$ in Figure 3). This approach follows the French school of data analysis (Benzécri 1973; Lebart et al. 1997). On the other hand, we use factor analysis to create a labour market segmentations index (3a in Figure 3).

Figure 3. Design of the analysis. The techniques and the analysis process

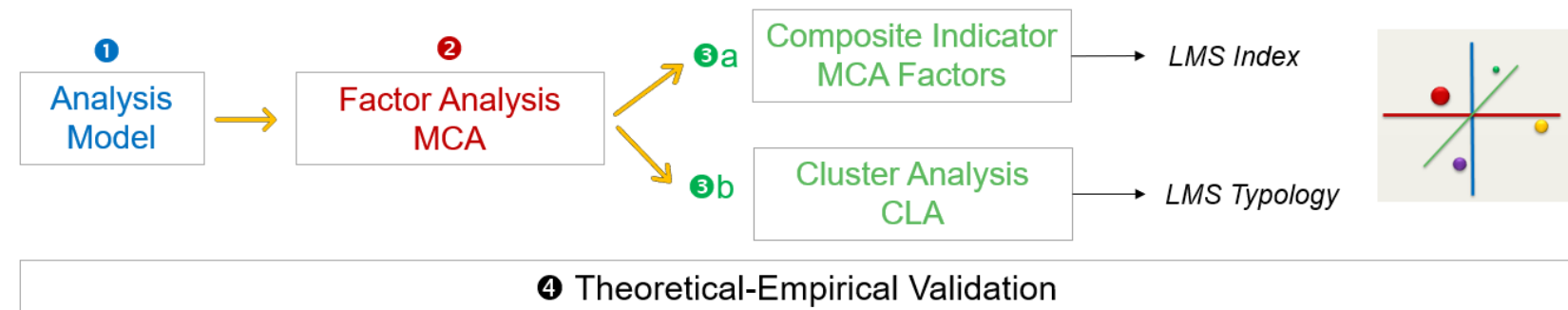

Source: Author

The results obtained with this analysis methodology may vary because of operational decisions regarding which variables are chosen and how they are coded or because of decisions resulting from the application of each analysis technique and the substantive interpretation of the results it provides. Therefore, it is essential to consider a further stage aimed at validating the result obtained both technically and theoretically.

To make a comparative analysis between Spain and Argentina, we first compare the structuring factors of the labour market in the two countries to see the degree of similarity. The main factors obtained with the multiple correspondence analysis also offer us, hierarchically, quantitative measures through factor scores, so we can develop a composite indicator through continuous synthetic measurement of the phenomenon, generating a labour market segmentation index (LMS index). In particular, if we take into account the first factor with a high percentage of explained variance, about $70 \%$, and we translate the origin to zero and converting all factor scores of the first axis $\left(F_{1 i}\right)$ into positive values:

$$
L M S I=F_{1 i}-\min \left(F_{1 i}\right)
$$

for each individual $i(i=1 \ldots n)$, we obtain a measurement of labour inequality one-dimensionally as a composite indicator.

Then, based on the main factors retained, we seek to obtain a typological variable that expresses the labour market segmentation for each country (LMS typology). It is also necessary to establish the degree of similarity of the labour segments obtained. This conglomeration analysis follows a mixed method: first, the individuals are classified according to the Ward ascendant hierarchical classification method, or the principle of minimal loss of inertia, and then, through a partition of the aggregation tree into a given number of groups, the initial classification is optimized by applying the mobile centres method (Lebart, 1997; López-Roldán y Fachelli, 2015).7

\footnotetext{
7 The factor and classification analyses were performed with the Système Portable pour 1 'Analyses de Donées (SPAD) software, version 5.5 .
} 
The labour market segmentation typology, formally, can be expressed in a simple way as a partition of a set of units. If $X$ is the data matrix with $n$ units, a partition in k groups or types is a collection of subsets of $\mathrm{X}$ that we call $\mathrm{T}_{\mathrm{i}}$ :

$$
L M S T=\left\{T_{i}\right\}=\left\{T_{1}, T_{2}, \ldots, T_{k}\right\}
$$

This classification is exhaustive, the union is the total set: $T_{1} \cup \ldots \cup T_{k}=X$, classes are exclusive: $T_{i} \cap T_{j}$ $=\varnothing$ for each $i \neq j$, and not empty: $T_{i} \neq \varnothing$. Additionally, although is not a generally necessary condition, each type or subset will be ordered if we analyse positions or inequalities in the social space (Blasius et al. 2019).

The typification of unequal positions in the labour market is obtained from a similar operationalization of the analysis model in both countries, in which we selected and prepared 13 original or manifest variables with 74 active categories (Table A1 of the Annex contains the frequency distribution of the variables used). For both Spain and Argentina, we worked with data from labour force surveys referring to 2016. For Spain we used the European Union Labour Force Survey (EU-LFS) and for Argentina we used the fourth quarter of the Permanent Household Survey of the National Institute of Statistics and Censuses (INDEC). The samples of the employed population were 30,037 and 17,798 workers, respectively.

\section{Results}

The results of this study are presented in two sections. In the first, the types of segmentation of employment in Spain and Argentina are constructed and compared, and the results of the dimensioning and classification analysis are presented. The second presents the results of the labour market segmentation index based on the factors obtained in the multiple correspondence analysis.

\subsection{Comparison of labour market segmentation typologies (LMS Typology)}

By applying a multiple correspondence factor analysis, we synthesized the set of categories of the original 13 variables that operationalized the segmentation model to two main factors (Table A2 of the Annex). After applying the correction suggested by Benzécri (1979), these two factors accumulated 86\% of the variance in the case of Spain and $88 \%$ in the case of Argentina. The two factors are highly similar in both countries (Figures 4 and 5 and Table A 3 of the Annex).

Figure 4. The social space of Spanish labour market segmentation 


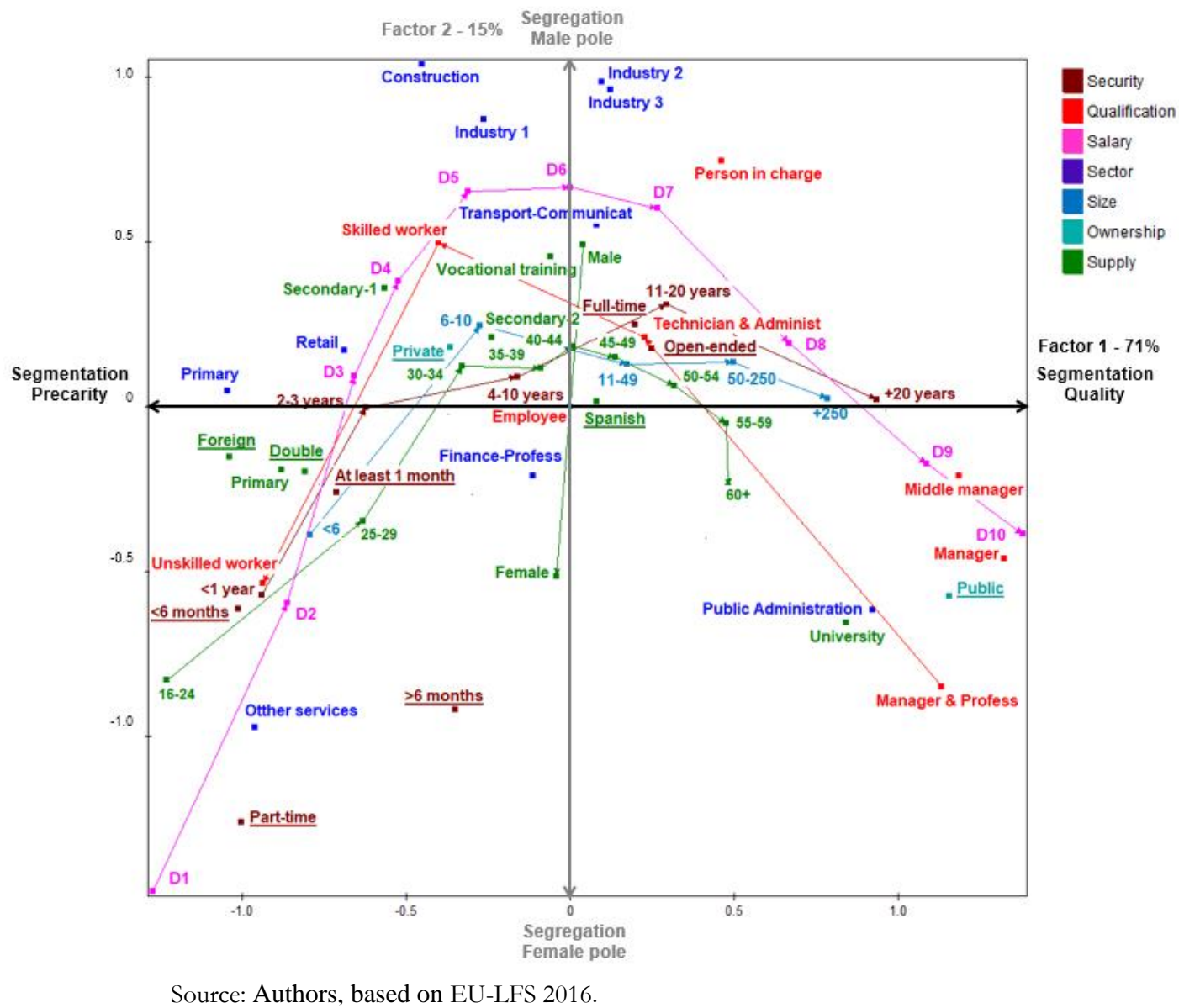

The first factor accumulates most of the explained variance, $71 \%$ in Spain and $72 \%$ in Argentina, so it represents a one-dimensional synthetic measure of the phenomenon of segmentation, as we will highlight in the following section. It is a fundamental axis of employment segmentation for the two countries that measures the main inequalities in the labour market by contrasting two extreme profiles. The first is a profile of job insecurity, with atypical jobs of poorer quality, that is, the most insecure ones because of short-term temporary employment, those based on informal employment relationships and those that are mostly part-time. They are the jobs with the lowest pay levels and are characteristic of small, privately owned companies, especially in the other services, construction and retail sectors (and also in the primary sector in the Spanish case). They are occupied by young people who have been in the company for a short time doing the least qualified jobs without supervisory responsibilities and with low levels of education. This profile includes part of the indigenous population but above all the population of immigrant origin.

At the opposite end we find the profile of safe, high-quality employment, i.e. formal open-ended contracts for full time jobs with seniority in the company. This profile identifies jobs with medium and high skill levels and with supervisory responsibilities, which are therefore occupied by workers with medium and high educational levels. They have the highest wage levels and are characteristic of medium-sized and large enterprises, especially in the public sector, but also in industry and part of the service sector: the public administration, education, health, transport and communications. This profile corresponds to adults who were born in the country. 


\section{Figure 5. The Social space of Argentinian Labour Market Segmentation}

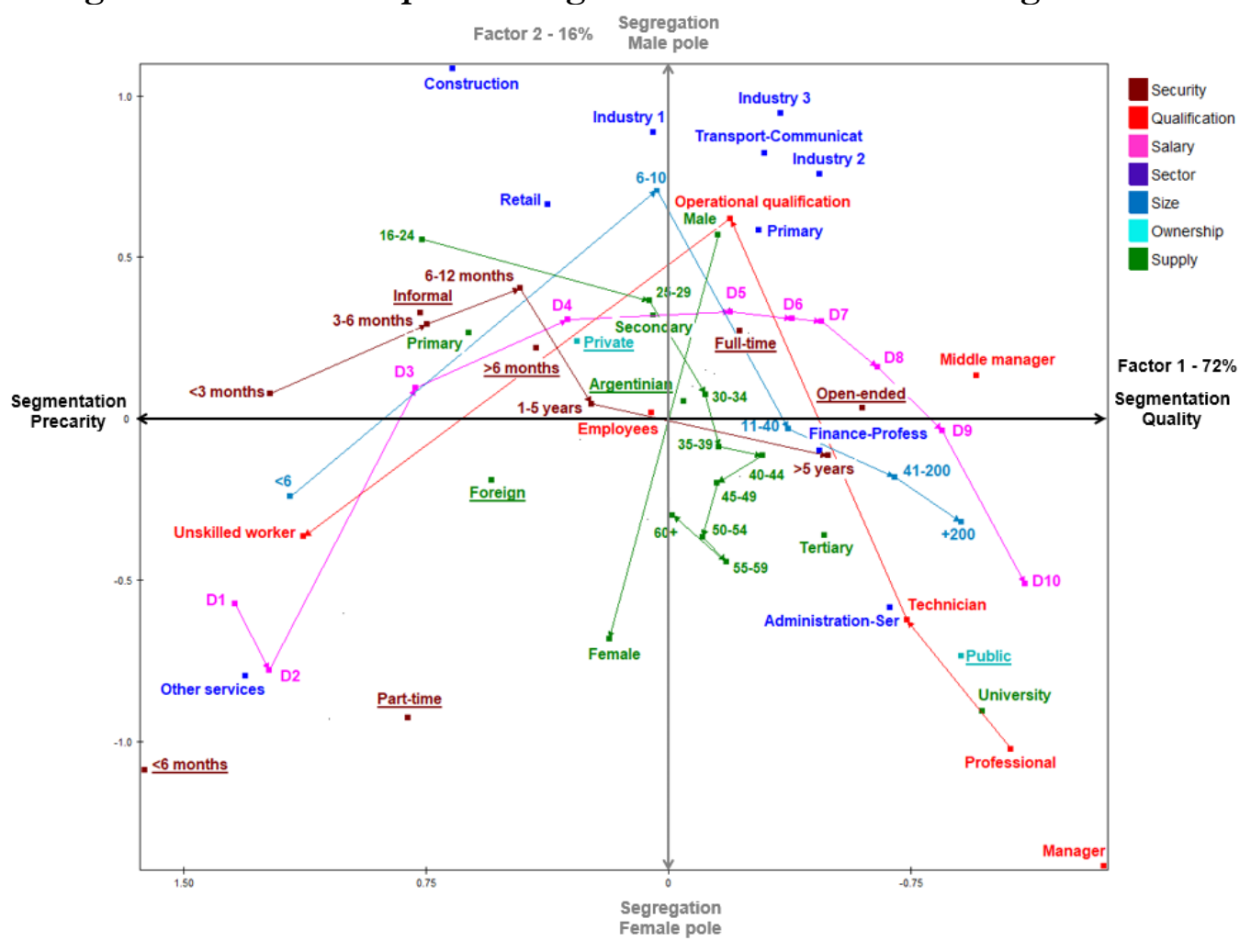

Source: Authors, based on EPH 2016.

Thus, an initial major factor of labour inequality between precarious and high-quality employment emerges, which we can summarize as employment segmentation between the profiles that the literature identifies as the primary and the secondary segment.

A second factor of lesser importance, that of segregation, accounting for $15 \%$ of the explained variance in Spain and 16\% in Argentina, adds an important complement to the first factor. It allows us to differentiate the intermediate positions from the extremes by drawing a point cloud with a parabolic shape, identifying the Guttman effect in the correspondence analysis (Lebart et al. 1997). The factorial axis differentiates the profile of the intermediate occupational levels of skilled or operative workers that are characteristic of private companies in industry, construction and transport. These features are shared by both countries, although in Spain the employment is stable, whereas in Argentina some of it is informal.

The opposite side unites here what appears separately in the first, because the low- and high-quality jobs in the service sector share the same space. This convergence of economic activities acquires its meaning through the contribution of the sex variable. This is a trait that was not introduced in the description of the first factorial axis because sex was neutral, but it now emerges to express a dimension of occupational segregation. The intermediate level end is occupied mainly by men and the service work end by women. This shows the greater employability of women in the service sector and the polarized behaviour of female employment between low and high occupational levels. In addition, there is an association between full-time work for men and part-time work for women. This dimension also helps account for a specific segmentation factor, because it helps distinguish between the lower primary and upper primary segments. We see basically the same results in both Spain and Argentina. 


\section{Figure 6. Employment segmentation typology}
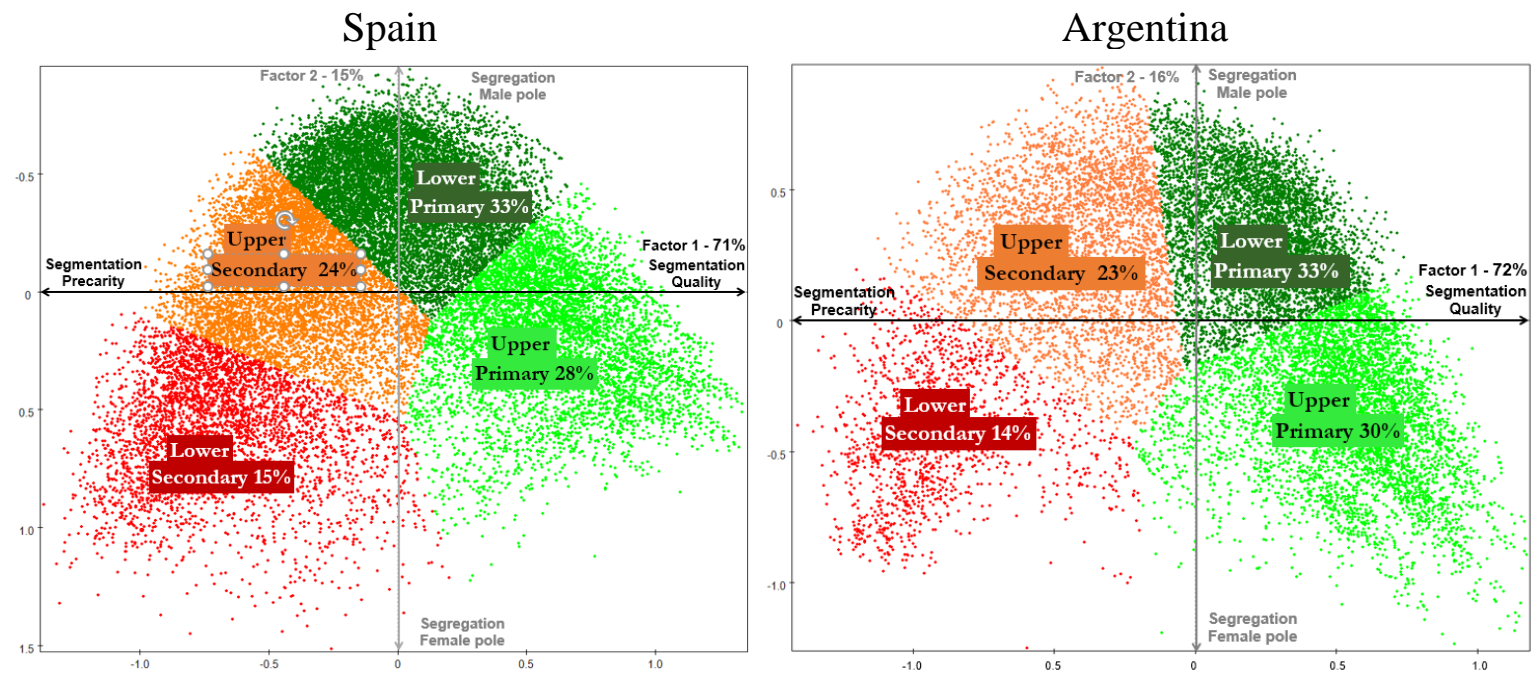

Source: Authors, based on EU-LFS 2016 and EPH 2016.

Based on these two main factors of employment segmentation, of labour inequality, we obtain the typology of segmentation by grouping workers who have the same profiles, thus generating the specific segments of employment. Taking the segmentation and segregation factors as classification criteria, after carrying out various validation exercises to ensure the stability of the results, the substantive relevance and the interpretative capacity, a typology was obtained for each country with four types of hierarchical stratification of the wage-earning population in the labour market. We summarize the profiles of the same segments that emerge in an equivalent way in each country. Figure 6 depicts in the factor space the individuals grouped in the employment segments obtained in the classification analysis and Table A4 of the Annex details the typology by significative categories.

Cluster 1 . This is the lower secondary segment, accounting for 15\% in Spain and 14\% in Argentina. It represents the most extreme profile in terms of job insecurity and low income. Job insecurity is accompanied by low skill levels in small private enterprises, especially those of other services, in parttime jobs with casual or informal contracts. It is a predominantly female type, of young people with a low level of education and mostly of immigrant origin.

Cluster 2. This is the upper secondary segment, accounting for $24 \%$ in Spain and $23 \%$ in Argentina. It shares with the previous one the low skill levels and job insecurity in small private companies characteristic of retail, other services, construction, finance-professional and the primary sector. It corresponds to low pay ranging from 1 to 4 deciles. The employees have little seniority in the company and tend to be mostly young, with primary or secondary education, and also with a higher relative presence of immigrants, but this cluster is somewhat more balanced according to sex than the previous one.

Cluster 3. This is the lowest primary segment, representing 33\% of the wage-earning population in both Spain and Argentina. It is characterized by stable full-time employment in skilled and technicaladministrative occupations, mainly in medium-sized or large private companies in industry, construction, retail and transport-communications. The employees have seniority in the company and their income is middle-high, between 4 and 8 deciles. It is a male-dominated segment with secondary education and vocational training levels, intermediate ages and a low presence of immigrants. 
Cluster 4. This is the highest primary segment, accounting for $28 \%$ of wage employment in Spain and $30 \%$ in Argentina. It is the type that enjoys the best conditions in the labour market: contractual security, high qualification, supervisory responsibilities, professional careers with seniority in the company and high pay. It is a characteristic profile of large companies and in particular of the public administration. The employees are mainly women, aged 40 years and over, indigenous and mostly with a university education.

We therefore conclude that there is a very high degree of similarity in the structure of the Spanish and Argentine labour markets in terms of the forms of recruitment, employment conditions, organizational context and social characteristics of the wage-earning population. The typological analysis shows a coinciding typification of unequal positions in wage employment, even at similar levels. It is important to note that these are relative similarities in the structuring of inequalities in the labour market resulting from a consideration of each social reality from inside. This result does not come into conflict with two complementary observations that qualify the differences between these two countries. First, the level of development and what we can call the absolute value of the inequalities places the two countries at different levels. In particular, for example, wage incomes move in a significantly different price range, although the social distances between the upper and lower segments are basically the same in both countries. Second, the phenomenon of segmentation, measured in terms of employment, can be conceptualized as an effect of the segmentation dynamics that generates these labour inequalities, but it is driven by demand factors, the institutional model or the productive structure, which in each sociohistorical context shape and explain specifically how these segments are configured, though they later coincide in their characterization from the point of view of employment.

\subsection{Comparison of labour market segmentation indexes (LMS index)}

The measurement of labour inequality in terms of an employment segmentation index (LMS Index) can be complemented by a simple quantitative measurement taking into account the first differentiation factor that emerged from the multiple correspondence analysis. As we saw in the previous section, the variance explained by the first main factor is very high, greater than $70 \%$, a criterion that in itself involves reaching the principle of parsimony that characterizes factor analysis: a loss of information to gain significance. Therefore, by discarding slightly less than $30 \%$ of the information (the least important part) provided by the original 13 variables, with their 74 associated categories, we managed to aggregate the measurement of labour inequality one-dimensionally into a single principal factor in terms of segmentation through a composite indicator. We did this by translating the origin to zero and converting all factor scores of the first axis into positive values.

Figure 7 depicts the point cloud with individuals in the factor space, highlighting the first factor axis as a composite indicator of labour inequality for both countries. The graph also shows the histogram of the index with the mean and the standard deviation. Taking the standard deviation as a measure of inequality in each country, we observe that the degree of relative inequality in Argentina is somewhat higher than that in Spain (0.572 versus 0.551). 
Figure 7. Labour Market Segmentation Index
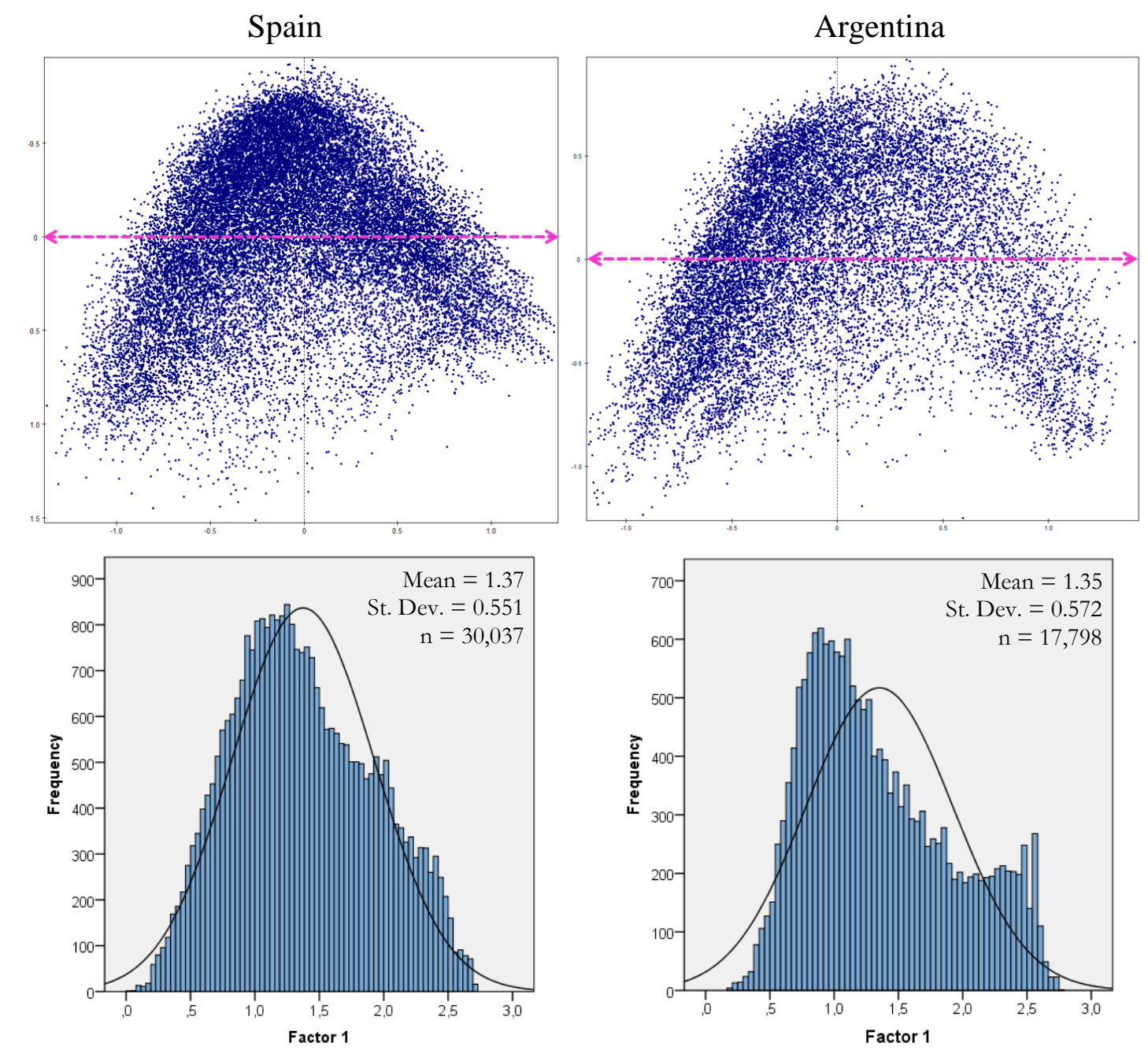

Source: Authors, based on EU-LFS 2016 and EPH 2016.

Finally, it should be noted that with this index of labour inequality we can make comparisons in both space and time. In López-Roldán et al. (2018) we applied a similar methodology for the comparative analysis between Spain and Italy and also compared the year 2009, at the beginning of the European economic crisis, with 2015, just at the end of it. Through this composite indicator, we found in particular a polarising effect of inequality resulting from the crisis, with the greatest impact in the Italian case. This measure can also be used in supplementary descriptive or explanatory analyses of the labour market or the living conditions of the population.

\section{Discussion and conclusions}

We found the existence of a common general pattern of structuring in the Spanish and Argentine labour markets in terms of segmentation, as we proposed in our hypothesis. We observed, in our first measure (LMS Typology), four employment segments that correspond to the profiles put forward by the segmentationist literature. Thus, two lines of division of wage employment were established. The main line of segmentation opposes precarious to high-quality employment, corresponding to the profiles of the primary and secondary segments, respectively. The second line of division introduces us to the sectoral segregation of employment associated with the gender dimension by contrasting a male profile of medium-qualified blue-collar work in industry with a female profile polarized between higherqualified white-collar work, especially in the public sector, and precarious unskilled work in services. 
The classification into four segments was observed in both Spain and Argentina, showing great similarity in the percentage distribution and, above all, in the dominant profiles that describe them. In both cases, moreover, we observed a correspondence between the structure of the labour market and the characteristics of both the supply and demand sides of the labour force. It is important to note that in both Spain and Argentina the types of segmentation are the relative expression of the labour realities specific to each region, so the grouping reflects characteristics with very similar features despite the different contexts of development and social regulation. The occupational and educational structure differ, and informality is a very distinctive phenomenon in Argentina, but despite the different socioproductive contexts, the structuring of inequalities in the labour markets of the two countries shows many common factors in the stratification of employment.

We are measuring qualitatively (LMS Typology) and quantitatively (LMS Index) labour realities that in historical and institutional terms are different, but where a process of operationalization and harmonization of basic variables considered on supply and demand of the labour market means that they can each other be compared in relative terms. Therefore, each of these societies internally has a level of inequality in the labour market that we could describe as "similar". This observation is of great interest because it transcends the apparent and real differences of socioeconomic development and allows us to indirectly observe the result of the mechanisms that have operated to generate inequalities in the labour market. We don't see the mechanisms; we see their result. Result that shows a surprising similarity in the pattern of configuration of employment inequalities.

These results invite us to explore this phenomenon further in future research by extending the case studies to a wide range of European and Latin American countries. We understand that the hypotheses of our research are oriented by our analytical approach and are subject to subsequent evidence and corroboration, which we will carry out in future work. We are currently carrying out a comparative analysis that also incorporates Italy and Chile (López Roldán et al. 2020) and have been able to corroborate similar results for all four countries.

We also aim to extend our analysis model on segmentation to take into account more complete and dynamic approaches. The problem we face in the comparative analysis between European and Latin American countries is the availability of suitable data. However, an explanatory model of the functioning of the labour market would gain in theoretical and analytical depth if we added the following features: the inclusion of independent workers to cover the whole of the employed population; the study of segmentation over time through a longitudinal study of the phenomenon; the dynamic analysis of occupation considering work trajectories and the processes of entry and exit from the labour market to observe microsocial processes; the link between the sphere of paid productive work and domestic reproductive work and personal care; systematization in the analysis of the institutional environment; and the implementation of a mixed methodology combing the quantitative and qualitative perspectives.

From the methodological point of view, the typology obtained is an interesting procedure for measuring social phenomena. In the field of social sciences, the construction of typologies as organizers of the conceptualizations of the complex social phenomena studied satisfies the need to classify or structure and, in general, to summarize the individuals, groups, institutions, societies or any other unit of analysis being studied into a small and meaningful set of categories or types. It has therefore been one of the most common procedures and objectives of empirical research, especially in the field of sociology, since the very origins of the discipline. The procedure followed here is a particular way of understanding typological construction and analysis: what we call structural and articulated typology (López-Roldán, 1996a). It is intended as an abstract and flexible model that can be applied to various theoretical contents. It is an instrument of conceptual operationalization, constructed by articulating theory with empirical reality (intensive and extensive) with a view to defining, structuring and measuring 
categorically the multidimensional complexity of social phenomena. This results in the constitution of a set of categories or types through the grouping of a universe of units combining simultaneously the characteristics or variables of their attribute space.

Moreover, the technical procedure followed offers the possibility of obtaining through factor analysis a continuous measure, in particular, of inequality in the labour market (LMS Index). Insofar as we can accumulate on the first factor axis most of the explained variance, more than $70 \%$, the factor variable obtained from the first axis constitutes a single synthetic measurement obtained empirically.

For future work, we can consider the fact that the variance accumulated by the first factor will not always reach these levels of one-dimensionality, so we must consider how to obtain a one-dimensional synthetic measure from two or more factors. An idea of how to measure in a multidimensional factor space what we can call "social distances", that is, the relative unequal positions of individuals in the analysis of a social phenomenon, was explored by Fachelli y López-Roldán (2013), who defined that distance as the measurement of social stratification. Finding a one-dimensional synthetic measure when ordinality is not repeated in the same sense in all the retained factors is therefore a pending objective. Asselin (2009) proposed a procedure for obtaining a composite indicator for the multidimensional measurement of poverty through the weighting of the categories of variables in each retained factor axis, which we are currently exploring for application to the measurement of social stratification.

From the initial findings presented in this article, we have pointed out different ways to continue research into the comparative analysis of social inequality, in particular in the labour markets of Europe and Latin America, as well as some methodological concerns for the measurement of inequalities using the proposed analytical procedure. We hope to make progress in these lines of work within the INCSI Network.

Acknowledgements This article was drafted within the context of the INCASI Network, a European project that has received funding from the European Union's Horizon 2020 research and innovation programme under the Marie Skłodowska-Curie GA No. 691004 and is coordinated by Dr. Pedro López-Roldán. This article reflects only the author's view and the Agency is not responsible for any use that may be made of the information it contains. 


\section{Appendix}

Table 2. Frequency distribution of employment segmentation variables. Salaried population employed in 2016. Spain and Argentina

\begin{tabular}{|c|c|c|c|c|c|c|}
\hline \multirow[b]{2}{*}{ Dimension } & \multicolumn{3}{|c|}{ Spain } & \multicolumn{3}{|c|}{ Argentina } \\
\hline & Variables & Frequency & $\%$ & Variables & Frequency & $\%$ \\
\hline \multirow{18}{*}{ 1. Security } & \multicolumn{6}{|c|}{ Type of contract and duration } \\
\hline & Open-ended & 22,472 & 75.6 & Open-ended & 10,885 & 61.2 \\
\hline & At least 1 month & 2,957 & 9.9 & - & & \\
\hline & $<6$ months & 2,580 & 8.7 & $<6$ months & 1,788 & 10.1 \\
\hline & $>6$ months & 1,714 & 5.8 & $>6$ months & 888 & 5.0 \\
\hline & - & & & Informal work & 4,226 & 23.8 \\
\hline & No data ${ }^{1}$ & $(314)$ & - & No data $^{1}$ & (9) & - \\
\hline & \multicolumn{6}{|c|}{ Seniority in the company } \\
\hline & $<1$ year & 5,260 & 17.5 & $<3$ months & 1,394 & 7.9 \\
\hline & $2-3$ years & 3,773 & 12.6 & 3-6 months & 782 & 4.4 \\
\hline & $4-10$ years & 7,080 & 23.6 & 6-12 months & 890 & 5.1 \\
\hline & $11-20$ years & 7,171 & 23.9 & $1-5$ years & 6,013 & 34.1 \\
\hline & \multirow{2}{*}{\multicolumn{3}{|c|}{$6,753 \quad 22.5$}} & $>5$ years & 8,542 & 48.5 \\
\hline & & & & No data ${ }^{1}$ & $(176)$ & - \\
\hline & \multicolumn{6}{|c|}{ Type of workday } \\
\hline & Full-time & 25,082 & 83.5 & Full-time & 13,378 & 77.8 \\
\hline & Part-time & 4,955 & 16.5 & Part-time & 3,817 & 22.2 \\
\hline & & & & No data ${ }^{1}$ & $(603)$ & - \\
\hline \multirow{12}{*}{ 2. Qualification } & \multicolumn{6}{|c|}{ Occupation } \\
\hline & $\begin{array}{l}\text { Managers and } \\
\text { professionals }\end{array}$ & 6,282 & 21.0 & Professional & 1,506 & 8.5 \\
\hline & $\begin{array}{c}\text { Technicians \& } \\
\text { administrative staff }\end{array}$ & 6,998 & 23.4 & Technician & 3,089 & 17.4 \\
\hline & Skilled workers & 12,343 & 41.4 & Operational qualification & 8,358 & 47.0 \\
\hline & Unskilled workers & 4,226 & 14.2 & Unskilled workers & 4,845 & 27.2 \\
\hline & No data ${ }^{1}$ & $(188)$ & - & No data ${ }^{1}$ & $(134)$ & - \\
\hline & \multicolumn{6}{|c|}{ Supervision } \\
\hline & Employee & 25,121 & 84.5 & Employee & 16,865 & 95.3 \\
\hline & Person in charge & 1,912 & 6.4 & - & & \\
\hline & Middle manager & 2,113 & 7.1 & Middle manager & 536 & 3.0 \\
\hline & Manager & 584 & 2.0 & Manager & 296 & 1.7 \\
\hline & No data ${ }^{1}$ & $(307)$ & - & No data ${ }^{1}$ & (53) & - \\
\hline \multirow{12}{*}{ 3. Salary } & \multicolumn{6}{|c|}{ Salary deciles } \\
\hline & Decile 1 & 2,949 & 9.8 & Decile 1 & 1,632 & 9.2 \\
\hline & Decile 2 & 2,832 & 9.4 & Decile 2 & 1,285 & 7.2 \\
\hline & Decile 3 & 2,904 & 9.7 & Decile 3 & 1,371 & 7.7 \\
\hline & Decile 4 & 3,017 & 10.0 & Decile 4 & 1,585 & 8.9 \\
\hline & Decile 5 & 2,906 & 9.7 & Decile 5 & 1,984 & 11.1 \\
\hline & Decile 6 & 3,086 & 10.3 & Decile 6 & 1,454 & 8.2 \\
\hline & Decile 7 & 2,991 & 10.0 & Decile 7 & 471 & 2.6 \\
\hline & Decile 8 & 3,074 & 10.2 & Decile 8 & 1,735 & 9.7 \\
\hline & Decile 9 & 3,163 & 10.5 & Decile 9 & 1,299 & 7.3 \\
\hline & Decile 10 & 3,115 & 10.4 & Decile 10 & 1,316 & 7.4 \\
\hline & & & & No data & 3,668 & 20.6 \\
\hline
\end{tabular}




\begin{tabular}{|c|c|c|c|c|c|c|}
\hline & & & Activi & sector & & \\
\hline & Primary & 809 & 2.7 & Primary & 185 & 1.1 \\
\hline & Industry 1 & 1,494 & 5.0 & Industry 1 & 1,088 & 6.2 \\
\hline & Industry 2 & 1,895 & 6.3 & Industry 2 & 393 & 2.2 \\
\hline & Industry 3 & 1,380 & 4.6 & Industry 3 & 806 & 4.6 \\
\hline & Construction & 1,454 & 4.8 & Construction & 1,170 & 6.7 \\
\hline & Retail & 6,302 & 21.0 & Retail & 2,274 & 13.0 \\
\hline & $\begin{array}{l}\text { Transport- } \\
\text { Communications }\end{array}$ & 2,129 & 7.1 & Transport-Communications & 1,387 & 7.9 \\
\hline & Financial-Professional & 3,536 & 11.8 & Financial-Professional & 1,003 & 5.7 \\
\hline & Public administration & 8,872 & 29.5 & Public administration & 6,163 & 35.2 \\
\hline & Other services & 2,166 & 7.2 & Other services & 3,040 & 17.4 \\
\hline Characterization & & & & No data ${ }^{1}$ & (245) & - \\
\hline & & Owner & ship c & he company & & \\
\hline & Public & 7,199 & 24.0 & Public & 4,348 & 24.4 \\
\hline & Private & 22,838 & 76.0 & Private & 13,450 & 75.6 \\
\hline & & & & No data ${ }^{1}$ & $(240)$ & - \\
\hline & & mpany s & ize $(n$ & nber of workers) & & \\
\hline & $<6$ & 5,270 & 17.5 & $<6$ & 4,767 & 26.8 \\
\hline & 6-10 & 2,132 & 7.1 & 6-10 & 1,679 & 9.4 \\
\hline & $11-49$ & 6,757 & 22.5 & $11-40$ & 2,684 & 15.1 \\
\hline & $50-250$ & 5,014 & 16.7 & $41-200$ & 2,255 & 12.7 \\
\hline & +250 & 4,428 & 14.7 & +200 & 2,632 & 14.8 \\
\hline & No data & 6,436 & 21.4 & No data & 3,782 & 21.3 \\
\hline & & & & & & \\
\hline 5. Gender & Male & 15,383 & 51.2 & Male & 9,707 & 54.5 \\
\hline & Female & 14,654 & 48.8 & Female & 8,091 & 45.5 \\
\hline & & & & & & \\
\hline & 16 to 24 years & 1,456 & & 16 to 24 years & 2,380 & 13.4 \\
\hline & 25 to 29 years & 2,388 & 8.0 & 25 to 29 years & 2,404 & 13.5 \\
\hline & 30 to 34 years & 2,959 & 9.9 & 30 to 34 years & 2,285 & 12.8 \\
\hline $6 \mathrm{Ams}$ & 35 to 39 years & 4,251 & 14.2 & 35 to 39 years & 2,497 & 14.0 \\
\hline 0. Age & 40 to 44 years & 4,662 & 15.5 & 40 to 44 years & 2,202 & 12.4 \\
\hline & 45 to 49 years & 4,491 & 15.0 & 45 to 49 years & 1,813 & 10.2 \\
\hline & 50 to 54 years & 4,385 & 14.6 & 50 to 54 years & 1,624 & 9.1 \\
\hline & 55 to 59 years & 3,569 & 11.9 & 55 to 59 years & 1,241 & 7.0 \\
\hline & $60+$ years & 1,876 & 6.2 & $60+$ years & 1,351 & 7.6 \\
\hline & & & Nati & ality & & \\
\hline & Spanish & 27,700 & 92.2 & Argentinian, this province & 14,482 & 81.4 \\
\hline 7. Immigration & Double nationality & 709 & 2.4 & Argentinian, another province & 2,400 & 13.5 \\
\hline & Foreign & 1,628 & 5.4 & Foreign & 909 & 5.1 \\
\hline & & & & No data ${ }^{1}$ & (6) & - \\
\hline & & & ducat & hal level & & \\
\hline & Primary & 1,448 & 4.8 & Primary & 5,942 & 33.5 \\
\hline Q Edurotion & Secondary $1^{\text {st }}$ stage & 8,124 & 27.0 & Secondary & 5,894 & 33.2 \\
\hline 8. Equcation & Secondary $2^{\text {nd }}$ stage & 7,027 & 23.4 & Tertiary & 3,510 & 19.8 \\
\hline & Vocational training & 4,187 & 13.9 & University & 2,394 & 13.5 \\
\hline & University & 9,251 & 30.8 & No data ${ }^{1}$ & $(59)$ & - \\
\hline
\end{tabular}




\begin{tabular}{|c|c|c|}
\hline Total & $30,037 \quad 100$ & $17,798 \quad 100$ \\
\hline & $\begin{array}{l}\text { Source: INE. EU-LFS } 2016 \text { (Encuesta de } \\
\text { Población Activa), annual data. } \\
\text { (1) Illustrative category with randomisation due } \\
\text { to low frequency (1.9\% or less). After cleaning, } \\
\text { of the } 74 \text { categories, } 66 \text { are considered actives. } \\
\text { (2) The grouping of sectors can be consulted in } \\
\text { the methodological information of the EPA. In } \\
\text { particular, Industry } 1 \text { is: food, textile, leather, } \\
\text { wood and paper; Industry 2: extractive, oil } \\
\text { refining, chemical, pharmaceutical, rubber and } \\
\text { plastics industries, and Industry } 3 \text { : construction } \\
\text { of machinery, electrical equipment, and } \\
\text { transport equipment, industrial installation and } \\
\text { repair. }\end{array}$ & $\begin{array}{l}\text { Source: INDEC. Encuesta Permanente de } \\
\text { Hogares, 2nd trimester, } 2016 . \\
\text { (1) Illustrative category with randomisation due to } \\
\text { low frequency (1.0\% or less). After cleaning, of the } \\
74 \text { categories, } 65 \text { are considered actives. } \\
\text { (2) The grouping was done based on CAES 1.0. It } \\
\text { was homogenized with the classification of Spain } \\
\text { and the different items are marked below: Industry } \\
\text { 1: idem as Spain. Industry 2: Idem as Spain + } \\
\text { Glass. Industry 3: Idem Spain + Manufacture of } \\
\text { Metals. Manufacture of Gas, electricity and steam. } \\
\text { Administration: Public Administration and } \\
\text { Support Services. Other services: Water, sewerage } \\
\text { and waste management; Accommodation and } \\
\text { food services; Employers domestic personnel. } \\
\text { (3) Amount for wages/salaries, family wages, } \\
\text { overtime, other bonuses and tickets. }\end{array}$ \\
\hline
\end{tabular}


Table 3. Multiple correspondence analysis results. Variances of axes (eigenvalues)

\begin{tabular}{|c|c|c|c|c|c|c|c|c|}
\hline & \multicolumn{4}{|c|}{ Spain } & \multicolumn{4}{|c|}{ Argentina } \\
\hline Factor $^{(1)}$ & Eigenvalue & $\begin{array}{r}\text { Benzécri } \\
\text { corrected } \\
\text { eigenvalue }\end{array}$ & $\begin{array}{r}\% \text { of } \\
\text { explained } \\
\text { variance }\end{array}$ & $\begin{array}{r}\text { Cumulated \% } \\
\text { of explained } \\
\text { variance }\end{array}$ & Eigenvalue & $\begin{array}{r}\text { Benzécri } \\
\text { corrected } \\
\text { eigenvalue } \\
\end{array}$ & $\begin{array}{r}\% \text { of } \\
\text { explained } \\
\text { variance }\end{array}$ & $\begin{array}{r}\text { Cumulated } \% \\
\text { of explained } \\
\text { variance }\end{array}$ \\
\hline 1 & 0.302 & 0.059 & $70.7 \%$ & $70.7 \%$ & 0.314 & 0.066 & $72.2 \%$ & $72.2 \%$ \\
\hline 2 & 0.180 & 0.012 & $14.7 \%$ & $85.4 \%$ & 0.188 & 0.015 & $15.9 \%$ & $88.2 \%$ \\
\hline 3 & 0.136 & 0.004 & $4.9 \%$ & $90.3 \%$ & 0.140 & 0.005 & $5.1 \%$ & $93.3 \%$ \\
\hline 4 & 0.128 & 0.003 & $3.6 \%$ & $94.0 \%$ & 0.131 & 0.003 & $3.7 \%$ & $97.0 \%$ \\
\hline 5 & 0.118 & 0.002 & $2.4 \%$ & $96.4 \%$ & 0.105 & 0.001 & $1.0 \%$ & $98.0 \%$ \\
\hline 6 & 0.109 & 0.001 & $1.5 \%$ & $97.8 \%$ & 0.099 & 0.001 & $0.6 \%$ & $98.6 \%$ \\
\hline 7 & 0.100 & 0.001 & $0.8 \%$ & $98.6 \%$ & 0.096 & 0.000 & $0.5 \%$ & $99.1 \%$ \\
\hline 8 & 0.095 & 0.000 & $0.4 \%$ & $99.0 \%$ & 0.093 & 0.000 & $0.3 \%$ & $99.4 \%$ \\
\hline 9 & 0.094 & 0.000 & $0.4 \%$ & $99.4 \%$ & 0.088 & 0.000 & $0.2 \%$ & $99.6 \%$ \\
\hline 10 & 0.091 & 0.000 & $0.3 \%$ & $99.7 \%$ & 0.088 & 0.000 & $0.2 \%$ & $99.7 \%$ \\
\hline 11 & 0.087 & 0.000 & $0.1 \%$ & $99.8 \%$ & 0.085 & 0.000 & $0.1 \%$ & $99.8 \%$ \\
\hline 12 & 0.084 & 0.000 & $0.1 \%$ & $99.9 \%$ & 0.085 & 0.000 & $0.1 \%$ & $99.9 \%$ \\
\hline 13 & 0.083 & 0.000 & $0.0 \%$ & $99.9 \%$ & 0.082 & 0.000 & $0.0 \%$ & $99.9 \%$ \\
\hline 14 & 0.081 & 0.000 & $0.0 \%$ & $100.0 \%$ & 0.082 & 0.000 & $0.0 \%$ & $99.9 \%$ \\
\hline 15 & 0.080 & 0.000 & $0.0 \%$ & $100.0 \%$ & 0.081 & 0.000 & $0.0 \%$ & $100.0 \%$ \\
\hline 16 & 0.080 & 0.000 & $0.0 \%$ & $100.0 \%$ & 0.080 & 0.000 & $0.0 \%$ & $100.0 \%$ \\
\hline 17 & 0.079 & 0.000 & $0.0 \%$ & $100.0 \%$ & 0.079 & 0.000 & $0.0 \%$ & $100.0 \%$ \\
\hline 18 & 0.079 & 0.000 & $0.0 \%$ & $100.0 \%$ & 0.079 & 0.000 & $0.0 \%$ & $100.0 \%$ \\
\hline 19 & 0.078 & 0.000 & $0.0 \%$ & $100.0 \%$ & 0.078 & 0.000 & $0.0 \%$ & $100.0 \%$ \\
\hline 20 & 0.078 & 0.000 & $0.0 \%$ & $100.0 \%$ & 0.078 & 0.000 & $0.0 \%$ & $100.0 \%$ \\
\hline 21 & 0.078 & 0.000 & $0.0 \%$ & $100.0 \%$ & 0.078 & 0.000 & $0.0 \%$ & $100.0 \%$ \\
\hline 22 & 0.077 & 0.000 & $0.0 \%$ & $100.0 \%$ & 0.077 & 0.000 & $0.0 \%$ & $100.0 \%$ \\
\hline Total & $4.078^{(2)}$ & 0.084 & $100.00 \%$ & & $4.004^{(2)}$ & 0.091 & $100.00 \%$ & \\
\hline
\end{tabular}

Source: own elaboration. For Spain: INE, Encuesta de Población Activa, 2016 annual data. For Argentina INDEC, Encuesta Permanente de Hogares, 2nd trimester. 2016.

(1) Retained factors according to Benzécri's criterion (values greater than the inverse of the number of variables).

(2) Original sum of eigenvalues. 
Table 4. Multiple correspondence analysis results. Absolute contributions

Spain

Argentina

\begin{tabular}{|c|c|c|c|c|c|c|}
\hline Variables & Categories & Axis 1 & Axis 2 & Categories & Axis 1 & Axis 2 \\
\hline \multirow{5}{*}{$\begin{array}{l}\text { Type of contract } \\
\text { and duration }\end{array}$} & Open-ended & 1.17 & 1.01 & Open-ended & 5.39 & 0.03 \\
\hline & At least 1 month & 1.28 & 0.29 & $<6$ months & 6.51 & 4.92 \\
\hline & $<6$ months & 2.25 & 1.39 & $>6$ months & 0.21 & 0.10 \\
\hline & $>6$ months & 0.18 & 2.06 & Informal work & 3.44 & 1.05 \\
\hline & & 4.89 & 4.76 & & 15.55 & 6.10 \\
\hline \multirow{6}{*}{$\begin{array}{l}\text { Seniority in the } \\
\text { company }\end{array}$} & $<1$ year & 3.96 & 2.46 & $<3$ months & 2.95 & 0.02 \\
\hline & $2-3$ years & 1.24 & $0.00 *$ & 3-6 months & 0.61 & 0.15 \\
\hline & $4-10$ years & 0.16 & 0.08 & 6-12 months & 0.26 & 0.33 \\
\hline & $11-20$ years & 0.53 & 1.00 & $1-5$ years & 0.47 & 0.03 \\
\hline & $>20$ years & 5.01 & $0.00 *$ & $>5$ years & 2.87 & 0.25 \\
\hline & & 10.89 & 3.55 & & 7.16 & 0.79 \\
\hline \multirow{3}{*}{ Type of workday } & Full-time & 0.83 & 2.21 & Full-time & 0.91 & 2.28 \\
\hline & Part-time & 4.22 & 11.22 & Part-time & 3.45 & 7.58 \\
\hline & & 5.05 & 13.43 & & 4.36 & 9.86 \\
\hline \multirow{5}{*}{ Occupation } & $\begin{array}{l}\text { Managers and } \\
\text { professionals }\end{array}$ & 6.85 & 6.50 & Professional & 2.31 & 3.60 \\
\hline & $\begin{array}{l}\text { Technicians } \\
\text { administrative staff }\end{array} \quad \&$ & 0.31 & 0.43 & Technician & 2.32 & 2.76 \\
\hline & Skilled workers & 1.68 & 4.36 & $\begin{array}{l}\text { Operational } \\
\text { qualification }\end{array}$ & 0.41 & 7.39 \\
\hline & Unskilled workers & 3.16 & 1.73 & Unskilled workers & 8.50 & 1.48 \\
\hline & & 12.00 & 13.02 & & 13.55 & 15.22 \\
\hline \multirow{5}{*}{ Supervision } & Employee & 0.57 & 0.02 & Employee & 0.07 & 0.01 \\
\hline & Person in charge & 0.34 & 1.52 & - & - & - \\
\hline & Middle manager & 2.52 & 0.13 & Middle manager & 0.67 & 0.02 \\
\hline & Manager & 0.87 & 0.18 & Manager & 0.75 & 1.32 \\
\hline & & 4.30 & 1.85 & & 1.49 & 1.35 \\
\hline \multirow{12}{*}{ Salary deciles } & Decile 1 & 4.06 & 9.09 & Decile 1 & 4.03 & 1.24 \\
\hline & Decile 2 & 1.78 & 1.44 & Decile 2 & 2.72 & 1.81 \\
\hline & Decile 3 & 1.07 & 0.04 & Decile 3 & 1.17 & 0.03 \\
\hline & Decile 4 & 0.71 & 0.63 & Decile 4 & 0.21 & 0.34 \\
\hline & Decile 5 & 0.24 & 1.76 & Decile 5 & 0.10 & 0.50 \\
\hline & Decile 6 & $0.00 *$ & 1.95 & Decile 6 & 0.29 & 0.32 \\
\hline & Decile 7 & 0.18 & 1.54 & Decile 7 & 0.15 & 0.10 \\
\hline & Decile 8 & 1.17 & 0.16 & Decile 8 & 1.00 & 0.10 \\
\hline & Decile 9 & 3.17 & 0.14 & Decile 9 & 1.29 & $0.00 *$ \\
\hline & Decile 10 & 5.03 & 0.66 & Decile 10 & 2.21 & 0.80 \\
\hline & - & - & - & No data & 0.10 & 0.16 \\
\hline & & 17.41 & 17.41 & & 13.26 & 5.40 \\
\hline \multirow{7}{*}{ Activity sector } & Primary & 0.75 & $0.00 *$ & Primary & 0.02 & 0.15 \\
\hline & Industry 1 & 0.09 & 1.62 & Industry 1 & $0.00 *$ & 1.98 \\
\hline & Industry 2 & 0.01 & 2.64 & Industry 2 & 0.12 & 0.52 \\
\hline & Industry 3 & 0.02 & 1.83 & Industry 3 & 0.13 & 1.66 \\
\hline & Construction & 0.25 & 2.25 & Construction & 0.73 & 3.18 \\
\hline & Retail & 2.54 & 0.27 & Retail & 0.44 & 2.32 \\
\hline & $\begin{array}{l}\text { Transport- } \\
\text { Communications }\end{array}$ & 0.01 & 0.93 & $\begin{array}{l}\text { Transport- } \\
\text { Communications }\end{array}$ & 0.17 & 2.16 \\
\hline
\end{tabular}




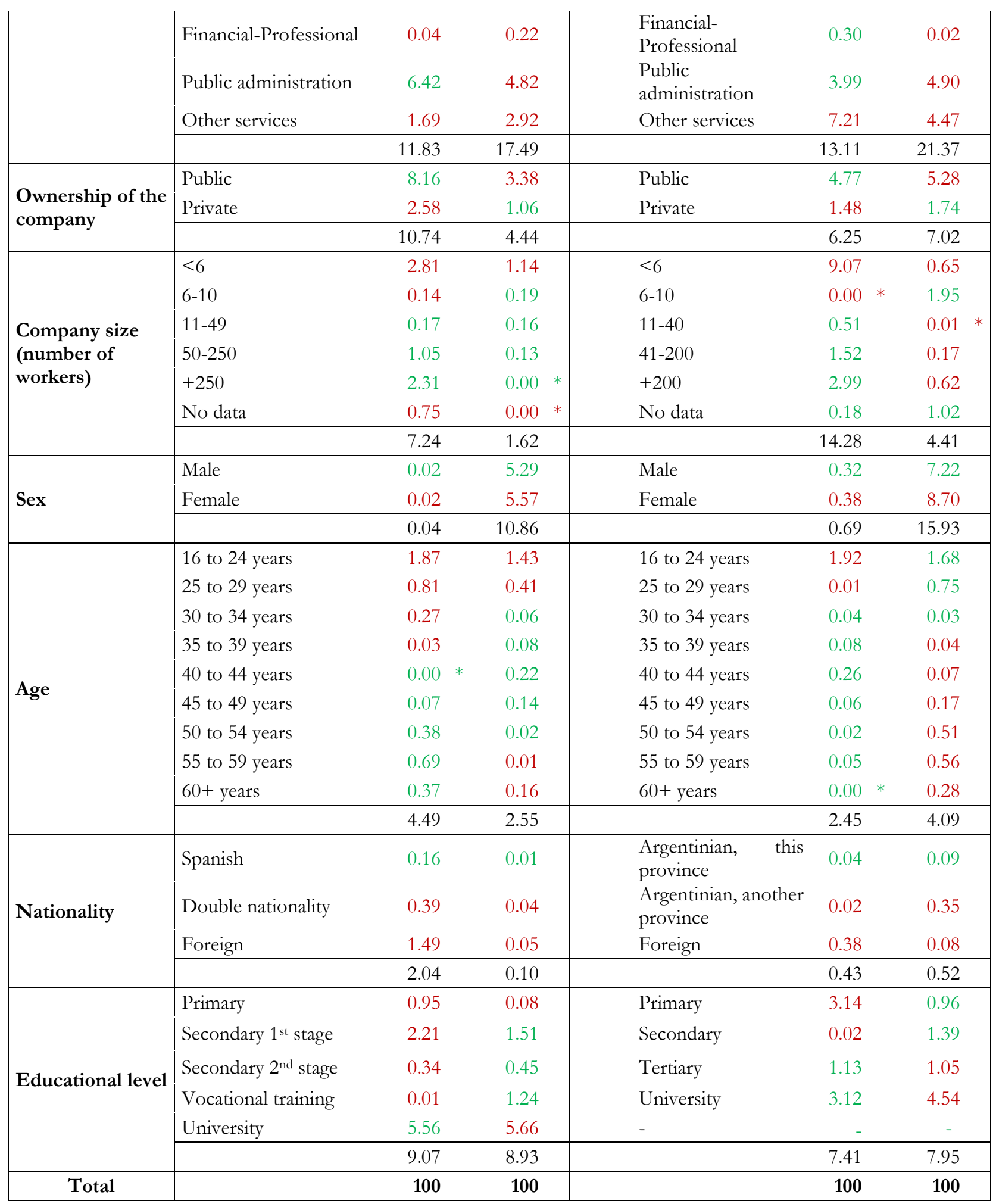

Source: own elaboration. For Spain: INE, Encuesta de Población Activa, 2016 annual data. For Argentina INDEC, Encuesta Permanente de Hogares, 2nd trimester. 2016.

In green positives coordinates, in red negative coordinates.

* Coordinate not significantly different from the mean (value 0). 
Table 5. Cluster analysis results. Characterization of the typology by significative categories

\begin{tabular}{|c|c|c|c|c|}
\hline \multicolumn{5}{|l|}{ Spain } \\
\hline Variable & Characteristic categories & $\begin{array}{r}\% \text { of } \\
\text { category in } \\
\text { group }\end{array}$ & $\begin{array}{r}\% \text { of } \\
\text { category in } \\
\text { set }\end{array}$ & $\begin{array}{r}\text { Difference of } \\
\text { proportions test- } \\
\text { value }\end{array}$ \\
\hline \multicolumn{5}{|c|}{ Cluster or Type 1: Lower Secondary Segment (4391 cases, $14.6 \%$ ) } \\
\hline Type of workday & Part-time & 79.8 & 16.5 & 106.3 \\
\hline Salary decile & D1 & 59.4 & 9.8 & 98.7 \\
\hline Seniority in the company & $<1$ year & 50.4 & 17.5 & 55.5 \\
\hline Occupation & Unskilled worker & 41.3 & 14.1 & 49.5 \\
\hline Activity sector & Other services & 27.7 & 7.2 & 47.6 \\
\hline Size of the company & $<6$ & 44.6 & 17.5 & 46.1 \\
\hline Sex & Female & 78.1 & 48.8 & 43.0 \\
\hline Age & $16-24$ & 18.9 & 4.8 & 39.0 \\
\hline Type of contract and duration & $<6$ months & 25.8 & 8.6 & 38.2 \\
\hline Salary decile & D2 & 26.6 & 9.4 & 36.8 \\
\hline Ownership of the company & Private & 93.3 & 76.0 & 32.2 \\
\hline Supervision & Employee & 97.3 & 83.6 & 30.9 \\
\hline Type of contract and duration & $>6$ months & 13.6 & 5.7 & 21.7 \\
\hline Type of contract and duration & $<1$ month & 19.0 & 9.8 & 20.3 \\
\hline Nationality & Foreign & 12.3 & 5.4 & 19.5 \\
\hline Age & $25-29$ & 15.4 & 8.0 & 18.0 \\
\hline Educational level & Primary & 10.8 & 4.8 & 17.8 \\
\hline Activity sector & Retail & 29.1 & 21.0 & 13.8 \\
\hline Size of the company & No data & 29.4 & 21.4 & 13.4 \\
\hline Seniority in the company & $2-3$ years & 18.9 & 12.6 & 13.1 \\
\hline Nationality & Double nationality & 4.9 & 2.4 & 10.6 \\
\hline Educational level & Secondary 1st stage & 33.6 & 27.0 & 10.4 \\
\hline Activity sector & Primary & 5.0 & 2.7 & 9.3 \\
\hline Activity sector & Financial-Professional & 15.7 & 11.8 & 8.4 \\
\hline Educational level & Secondary 2nd stage & 25.0 & 23.4 & 2.6 \\
\hline \multicolumn{5}{|c|}{ Cluster or Type 2: Upper Secondary Segment (7256 cases, $24.2 \%$ ) } \\
\hline Ownership of the company & Private & 96.2 & 76.0 & 52.4 \\
\hline Salary decile & D3 & 25.4 & 9.7 & 47.8 \\
\hline Activity sector & Retail & 37.1 & 21.0 & 37.1 \\
\hline Supervision & Employee & 95.7 & 83.6 & 35.5 \\
\hline Salary decile & D4 & 21.7 & 10.0 & 35.2 \\
\hline Seniority in the company & $<1$ year & 31.4 & 17.5 & 34.1 \\
\hline Salary decile & D2 & 20.2 & 9.4 & 33.5 \\
\hline Occupation & Unskilled worker & 24.3 & 14.1 & 27.4 \\
\hline Occupation & Skilled worker & 53.6 & 41.1 & 24.6 \\
\hline Type of contract and duration & $<6$ months & 16.1 & 8.6 & 24.5 \\
\hline Size of the company & $<6$ & 27.4 & 17.5 & 24.4 \\
\hline Seniority in the company & $2-3$ years & 21.2 & 12.6 & 24.3 \\
\hline Educational level & Secondary 1st stage & 38.2 & 27.0 & 24.0 \\
\hline Type of contract and duration & $<1$ month & 17.4 & 9.8 & 23.3 \\
\hline Age & $25-29$ & 14.1 & 8.0 & 21.0 \\
\hline Nationality & Foreign & 10.4 & 5.4 & 20.2 \\
\hline Educational level & Primary & 9.0 & 4.8 & 17.7 \\
\hline
\end{tabular}




\begin{tabular}{|c|c|c|c|c|}
\hline Size of the company & No data & 29.1 & 21.4 & 17.7 \\
\hline Activity sector & Primary & 5.8 & 2.7 & 17.5 \\
\hline Age & $16-24$ & 7.8 & 4.8 & 12.6 \\
\hline Salary decile & D5 & 13.3 & 9.7 & 11.7 \\
\hline Nationality & Española y doble & 4.2 & 2.4 & 10.9 \\
\hline Age & $30-34$ & 13.2 & 9.9 & 10.6 \\
\hline Seniority in the company & $4-10$ years & 27.8 & 23.6 & 9.5 \\
\hline Sex & Female & 53.3 & 48.8 & 8.9 \\
\hline Educational level & Secondary 2nd stage & 27.2 & 23.4 & 8.7 \\
\hline Size of the company & $6-10$ & 9.4 & 7.1 & 8.5 \\
\hline Activity sector & Construction & 6.7 & 4.8 & 8.2 \\
\hline Type of contract and duration & $>6$ months & 7.3 & 5.7 & 6.4 \\
\hline Activity sector & Financial-Professional & 13.8 & 11.8 & 5.9 \\
\hline Activity sector & Other services & 8.8 & 7.2 & 5.9 \\
\hline Type of workday & Full-time & 85.4 & 83.5 & 5.1 \\
\hline Age & $35-39$ & 15.5 & 14.2 & 3.7 \\
\hline \multicolumn{5}{|c|}{ Cluster or Type 3: Segment Primary inferior (9900 cases, $33.0 \%)$} \\
\hline Type of workday & \begin{tabular}{|l|l} 
Full-time & \\
\end{tabular} & 99.6 & 83.5 & 63.3 \\
\hline Sex & Male & 74.9 & 51.2 & 58.7 \\
\hline Type of contract and duration & Open-ended & 92.1 & 74.8 & 52.1 \\
\hline Ownership of the company & Private & 92.8 & 76.0 & 51.6 \\
\hline Occupation & Skilled worker & 59.3 & 41.1 & 44.9 \\
\hline Activity sector & Industry 2 & 14.0 & 6.3 & 37.0 \\
\hline Salary decile & D6 & 19.3 & 10.3 & 34.7 \\
\hline Salary decile & D7 & 18.3 & 10.0 & 32.7 \\
\hline Activity sector & Industry 3 & 10.2 & 4.6 & 31.1 \\
\hline Seniority in the company & $11-20$ years & 34.7 & 23.9 & 30.2 \\
\hline Educational level & Vocational training & 22.0 & 13.9 & 27.5 \\
\hline Supervision & Person in charge & 12.1 & 6.4 & 27.3 \\
\hline Salary decile & D5 & 16.5 & 9.7 & 27.0 \\
\hline Activity sector & Industry 1 & 9.9 & 5.0 & 26.3 \\
\hline Occupation & Technicians \& administrative staff & 32.3 & 23.3 & 25.5 \\
\hline Educational level & Secondary 1st stage & 35.9 & 27.0 & 24.0 \\
\hline Activity sector & Transport-Communications & 12.1 & 7.1 & 22.8 \\
\hline Activity sector & Construction & 8.8 & 4.8 & 21.5 \\
\hline Nationality & Spanish & 96.0 & 92.2 & 18.1 \\
\hline Size of the company & $11-49$ & 27.2 & 22.5 & 13.6 \\
\hline Salary decile & D8 & 13.6 & 10.2 & 13.4 \\
\hline Educational level & Secondary 2nd stage & 27.9 & 23.4 & 12.9 \\
\hline Size of the company & $50-250$ & 20.1 & 16.7 & 11.1 \\
\hline Age & $40-44$ & 18.6 & 15.5 & 10.3 \\
\hline Seniority in the company & $4-10$ years & 26.6 & 23.6 & 8.7 \\
\hline Age & $45-49$ & 17.3 & 15.0 & 8.0 \\
\hline Size of the company & $6-10$ & 8.4 & 7.1 & 5.9 \\
\hline Age & $35-39$ & 15.8 & 14.2 & 5.6 \\
\hline Age & $50-54$ & 16.1 & 14.6 & 5.2 \\
\hline Salary decile & D4 & 11.1 & 10.0 & 4.3 \\
\hline Seniority in the company & $>20$ years & 23.9 & 22.5 & 4.1 \\
\hline Age & $30-34$ & 10.8 & 9.9 & 3.9 \\
\hline
\end{tabular}




\begin{tabular}{|l|l|r|r|r|}
\hline \multicolumn{2}{|c|}{ Cluster or Type 4: Segment Primary superior (8490 cases, 28.3\%) } \\
\hline & Retail sector & 69.7 & 24.0 & 2.0 \\
\hline Ownership of the company & Public & 75.7 & 29.5 & 113.8 \\
\hline Activity sector & Public administration & 62.4 & 20.9 & 108.7 \\
\hline Occupation & Managers and professionals & 74.6 & 30.8 & 107.6 \\
\hline Educational level & University & 30.1 & 10.4 & 101.9 \\
\hline Salary decile & D10 & 46.5 & 22.5 & 66.5 \\
\hline Seniority in the company & $>20$ years & 26.4 & 10.5 & 60.3 \\
\hline Salary decile & D & 18.5 & 7.0 & 53.0 \\
\hline Supervision & Middle manager & 28.7 & 14.7 & 45.7 \\
\hline Size of the company & $250+$ & 95.8 & 83.5 & 40.9 \\
\hline Type of workday & Full-time & 87.8 & 74.8 & 40.0 \\
\hline Type of contract and duration & Open-ended & 98.5 & 92.2 & 34.2 \\
\hline Nationality & Spanish & 18.5 & 10.2 & 29.0 \\
\hline Salary decile & D8 & 24.6 & 16.7 & 28.4 \\
\hline Size of the company & $50-250$ & 17.9 & 11.9 & 22.4 \\
\hline Age & $55-59$ & 57.4 & 48.8 & 19.6 \\
\hline Sex & Female & 10.2 & 6.2 & 18.8 \\
\hline Age & $60+$ & 19.0 & 14.6 & 16.8 \\
\hline Age & $50-54$ & 27.5 & 23.9 & 13.2 \\
\hline Seniority in the company & $11-20$ years & 25.1 & 22.5 & 9.0 \\
\hline Size of the company & $11-49$ & 16.1 & 15.0 & 6.8 \\
\hline Age & $45-49$ & & 3.4 \\
\hline
\end{tabular}

Argentina
\begin{tabular}{|l|l|r|r|r|}
\hline Variable & Characteristic categories & $\begin{array}{r}\text { \% of category } \\
\text { in group }\end{array}$ & $\begin{array}{r}\text { \% of } \\
\text { category in } \\
\text { set }\end{array}$ & $\begin{array}{r}\text { Difference of } \\
\text { proportions test-value }\end{array}$ \\
\hline \multicolumn{2}{|c|}{ Cluster or Type 1: Lower Secondary Segment, (2471 cases, 13.9\%) } \\
\hline Activity sector & Other services & 81.0 & 17.1 & 79.2 \\
\hline Occupation & Unskilled worker & 93.4 & 26.9 & 77.1 \\
\hline Size of the company & $<6$ & 89.6 & 26.8 & 72.2 \\
\hline Type of contract and duration & $<6$ months & 58.9 & 10.0 & 71.0 \\
\hline Type of workday & Part-time & 70.7 & 21.4 & 58.1 \\
\hline Sex & Female & 90.2 & 45.5 & 50.5 \\
\hline Salary decile & D1 & 36.2 & 9.2 & 42.0 \\
\hline Salary decile & D2 & 29.9 & 7.2 & 38.6 \\
\hline Educational level & Primary & 60.4 & 33.4 & 29.7 \\
\hline Ownership of the company & Private & 95.7 & 74.9 & 29.6 \\
\hline Seniority in the company & $<3$ months & 22.1 & 7.8 & 24.7 \\
\hline Type of contract and duration & Informal & 35.8 & 23.7 & 14.6 \\
\hline Supervision & Employee & 99.4 & 94.8 & 13.6 \\
\hline Nationality & Foreign & 11.0 & 5.1 & 12.8 \\
\hline Nationality & Argentinian, other province & 20.5 & 13.5 & 10.4 \\
\hline Seniority in the company & $1-5$ years & 42.6 & 33.8 & 9.8 \\
\hline Seniority in the company & $3-6$ months & 8.2 & 4.4 & 9.0 \\
\hline Salary decile & D3 & 12.2 & 7.7 & 8.4 \\
\hline Age & $50-54$ & 12.7 & 9.1 & 6.3 \\
\hline Age & $55-59$ & 9.5 & 7.0 & 5.1 \\
\hline
\end{tabular}




\begin{tabular}{|c|c|c|c|c|}
\hline Age & $16-24$ & 16.3 & 13.4 & 4.4 \\
\hline Age & $60+$ & 9.8 & 7.6 & 4.2 \\
\hline \multicolumn{5}{|c|}{ Cluster or Type 2: Upper Secondary Segment (4061 cases, $22.8 \%$ ) } \\
\hline Type of contract and duration & Informal & 58.6 & 23.7 & 56.2 \\
\hline Ownership of the company & Private & 95.1 & 74.9 & 37.9 \\
\hline Age & $16-24$ & 32.4 & 13.4 & 37.4 \\
\hline Size of the company & $<6$ & 48.6 & 26.8 & 34.4 \\
\hline Activity sector & Construction & 19.2 & 6.6 & 33.4 \\
\hline Educational level & Primary & 52.1 & 33.4 & 28.1 \\
\hline Activity sector & Retail & 26.6 & 12.8 & 28.1 \\
\hline Salary decile & D3 & 18.8 & 7.7 & 27.5 \\
\hline Occupation & Unskilled worker & 42.4 & 26.9 & 24.6 \\
\hline Seniority in the company & $<3$ months & 17.6 & 7.8 & 24.2 \\
\hline Sex & Male & 68.2 & 54.5 & 20.1 \\
\hline Type of contract and duration & $>6$ months & 11.4 & 5.0 & 19.4 \\
\hline Salary decile & D4 & 16.6 & 8.9 & 18.2 \\
\hline Supervision & Employee & 99.3 & 94.8 & 17.3 \\
\hline Seniority in the company & 6-12 months & 10.4 & 5.0 & 16.5 \\
\hline Seniority in the company & 3-6 months & 8.9 & 4.4 & 14.6 \\
\hline Seniority in the company & $1-5$ years & 40.8 & 33.8 & 10.6 \\
\hline Size of the company & $6-10$ & 13.9 & 9.4 & 10.5 \\
\hline Salary decile & D1 & 13.2 & 9.2 & 9.7 \\
\hline Age & $25-29$ & 18.1 & 13.5 & 9.4 \\
\hline Occupation & Operational qualification & 52.2 & 46.7 & 7.9 \\
\hline Activity sector & Industry 1 & 8.6 & 6.1 & 7.1 \\
\hline Salary decile & $\mathrm{D} 2$ & 9.3 & 7.2 & 5.7 \\
\hline Nationality & Argentinian, this province & 84.2 & 81.4 & 5.3 \\
\hline Nationality & Foreign & 6.5 & 5.1 & 4.3 \\
\hline Educational level & Secondary & 35.6 & 33.1 & 3.8 \\
\hline Type of workday & Full-time & 77.4 & 75.2 & 3.8 \\
\hline \multicolumn{5}{|c|}{ Cluster or Type 3: Segment Primary inferior $(5820,32.7 \%)$} \\
\hline Occupation & Operational qualification & 78.7 & 46.7 & 60.8 \\
\hline Type of contract and duration & Open-ended & 87.1 & 61.2 & 52.1 \\
\hline Sex & Male & 80.4 & 54.5 & 49.8 \\
\hline Type of workday & Full-time & 94.6 & 75.2 & 46.0 \\
\hline Ownership of the company & Private & 89.8 & 74.9 & 33.8 \\
\hline Activity sector & Transport-Communications & 16.3 & 7.8 & 28.5 \\
\hline Educational level & Secondary & 46.4 & 33.1 & 25.9 \\
\hline Activity sector & Industry 3 & 10.2 & 4.5 & 24.4 \\
\hline Size of the company & No data & 31.3 & 21.3 & 22.3 \\
\hline Activity sector & Industry 1 & 11.4 & 6.1 & $\overline{19.6}$ \\
\hline Salary decile & D8 & 15.9 & 9.7 & 18.5 \\
\hline Seniority in the company & $>5$ years & 57.5 & 48.0 & 17.8 \\
\hline Salary decile & D6 & 13.2 & 8.2 & 16.4 \\
\hline Size of the company & $6-10$ & 14.5 & 9.4 & 15.7 \\
\hline Activity sector & Industry 2 & 4.7 & 2.2 & 14.9 \\
\hline Salary decile & D5 & 15.3 & 11.1 & 12.1 \\
\hline Salary decile & D7 & 4.5 & 2.6 & 10.1 \\
\hline Salary decile & D9 & 10.0 & 7.3 & 9.5 \\
\hline
\end{tabular}




\begin{tabular}{|c|c|c|c|c|}
\hline Activity sector & Retail & 16.2 & 12.8 & 9.4 \\
\hline Age & $25-29$ & 16.7 & 13.5 & 8.6 \\
\hline Size of the company & $11-40$ & 18.2 & 15.1 & 7.9 \\
\hline Age & $30-34$ & 15.6 & 12.8 & 7.5 \\
\hline Supervision & Middle manager & 4.4 & 3.0 & 7.2 \\
\hline Salary decile & No data & 23.6 & 20.6 & 6.9 \\
\hline Size of the company & $41-200$ & 14.9 & 12.7 & 6.1 \\
\hline Nationality & Argentinian, this province & 83.3 & 81.4 & 4.6 \\
\hline Activity sector & Financial-Professional & 6.4 & 5.6 & 3.2 \\
\hline \multicolumn{5}{|c|}{ Cluster or Type 4: Segment Primary superior (5446 cases, 30.6\%) } \\
\hline Ownership of the company & Public & 63.9 & 23.6 & 82.8 \\
\hline Activity sector & Public administration & 78.9 & 34.6 & 82.8 \\
\hline Educational level & University & 38.0 & 13.5 & 61.7 \\
\hline Occupation & Technician & 41.6 & 17.3 & 54.8 \\
\hline Type of contract and duration & Open-ended & 88.7 & 61.2 & 53.1 \\
\hline Occupation & Professional & 24.5 & 8.3 & 50.3 \\
\hline Seniority in the company & $>5$ years & 70.4 & 48.0 & 40.1 \\
\hline Size of the company & $200+$ & 31.1 & 14.8 & 39.0 \\
\hline Educational level & Tertiary & 35.7 & 19.7 & 34.3 \\
\hline Salary decile & D10 & 17.5 & 7.4 & 32.5 \\
\hline Sex & Female & 63.0 & 45.5 & 31.3 \\
\hline Size of the company & $41-200$ & 22.8 & 12.7 & 25.8 \\
\hline Salary decile & D9 & 12.5 & 7.3 & 16.8 \\
\hline Size of the company & $11-40$ & 20.7 & 15.1 & 13.5 \\
\hline Age & $40-44$ & 16.4 & 12.4 & 10.4 \\
\hline Salary decile & $\mathrm{D} 8$ & 13.1 & 9.7 & 9.7 \\
\hline Age & $55-59$ & 9.7 & 7.0 & 9.4 \\
\hline Activity sector & Financial-Professional & 8.1 & 5.6 & 9.4 \\
\hline Supervision & Middle manager & 4.8 & 3.0 & 8.9 \\
\hline Age & $50-54$ & 11.8 & 9.1 & 8.0 \\
\hline Age & $35-39$ & 17.0 & 14.0 & 7.5 \\
\hline Age & $45-49$ & 12.8 & 10.2 & 7.4 \\
\hline Type of workday & No data & 4.6 & 3.4 & 5.6 \\
\hline Nationality & Argentinian, this province & 83.1 & 81.4 & 3.9 \\
\hline Age & $60+$ & 8.6 & 7.6 & 3.4 \\
\hline
\end{tabular}

\section{References}

Alós, R., Beneyto, P., \& Jódar, P. (2017). Reforma laboral y desregulación del mercado de trabajo. Anuario IET de Trabajo y Relaciones Laborales, 5, 73-86. http://revistes.uab.cat/anuarioiet/article/view/v4-alos-beneyto-jodar/55-pdf-es

Arrighi, G. (1985). Semiperipheral Development: The Politics of Southern Europe in the Twentieth Century. Beverly Hills: Sage.

Asselin, L.-M. (2009). Analysis of Multidimensional Poverty. Theory and Case Studies. Ottawa: Springer.

Banyuls, J., Miguélez, F., Recio, A., Cano, E., \& Lorente, R. (2009). The Transformation of the Employment System in Spain: Towards a Mediterranean Neoliberalism? In: Bosch, G., Lehndorff, S., \& Rubery, J (Ed.), European Employment Models in Flux. A Comparison of 
Institutional Change in Nine European Countries (pp. 247-269). Basingstoke: Palgrave Macmillan. https://doi.org/10.1057/9780230237001 10

Banyuls, J., \& Recio, A. (2017). Labour segmentation and precariousness in Spain: theories and evidence. In: D. Grimshaw, C. Fagan., G. Hebson \& I. Tavora (Eds.), Making work more equal: A new labour segmentation approach (pp. 129-149). Manchester: Manchester University Press. http://www.oapen.org/search?identifier $=634747$

Benzécri, J.-P. (1973). L'analyse des données. Paris: Dunod.

Benzécri, J.-P. (1979). Sur le calcul de taux d'inertie dans l'analyse d'un questionnaire. Les Cabiers de l'Analyse des Données, 4, 377-378.

Blasius, J., Lebaron, F., Le Roux, B. \& Schmitz, A. (2019). Empirical Investigations of Social Space. Charm,

Switzerland: Springer.

Burroni, L. (2016). Capitalismi a confronto. Milano: Il Mulino.

Craig, C., Rubery, J., Tarling, R., \& Wilkinson, F. (1982). Labour Market Structure, Industrial Organisation and Low Pay. Cambridge: Cambridge University Press.

Dickens, W. T. \& Lang, K. (1988). The Reemergence of Segmented Labor Market Theory. The American Economic Review, 78(2), 129-134.

Doeringer, P. P., \& Piore, M. J. M. (1971). Internal labor markets and manpower analysis. New York: D.C. Heath and Company.

Fachelli, S.; López, N; López-Roldán, P. \& Sourrouille, F. (2012). Desigualdad y diversidad en América Latina: hacia un análisis tipológico comparado. International Institute for Educational Planning IIPE- UNESCO. Buenos Aires.

Fachelli, S. \& López-Roldán, P. (2013). An attempt to measure social stratification and changes in terms of social distances. Dipòsit Digital de Documents Biblioteca de Ciències Socials. Barcelona: Universitat Autònoma de Barcelona. Retrieve from https ://ddd.uab.cat/recor d/11379 1.

Fina, Ll. \& Toharia, L. (1987). Las causas del paro en España: Un punto de vista estructural. Madrid: Fundación Instituto de Estudios Sociales Avanzados.

Gordon, D. M., Edwards, R., \& Reich, M. (1982). Segmented work, divided workers: The historical transformation of labor in the United States. Cambridge: Cambridge University Press.

Grimshaw, D., \& Rubery, J. (2005). Inter-capital relations and network organisation: redefining the work and employment nexus. Cambridge Journal of Economics, 29, 1027-1051.

Grimshaw, D., Fagan, C., Hebson, G., \& Tavora, I. (Eds.). (2017). Making work more equal: A new labour segmentation approach. Manchester: Manchester University Press Gibert (2011).

Hacker, J. S. (2011). The institutional foundation of midle-class democracy. Nertwork Policy, 6, 33-37.

International Labour Office (ILO) (2016). Non-standard employment around the world: Understanding challenges, shaping prospects. Geneva: ILO.

Ishida, H., \& Miwa, S. (Eds). (2011). Comparative Social Mobility and Late Industrialization. Yale University (January): Workshop of the Center for Research on Inequalities and the Life Course (CIQLE).

Lebart, L., Morineau, A., \& Piron, M. (1997). Statistique exploratoire multidimensionnelle. Paris: Dunod.

López-Roldán, P. (1996a). "La construcción de tipologías: metodología de análisis". Papers. Revista de Sociologia, 48, 9-29. https://doi.org/10.5565/rev/papers.1811.

López-Roldán, P. (1996b). "La construcción de una tipología de segmentación del mercado de trabajo". Papers. Revista de Sociologia, 48, 41-58. https://doi.org/10.5565/rev/papers.1812.

López-Roldán, P.; Miguélez, F.; Lope, A. \& Coller, X. (1998). "La segmentación laboral: hacia una tipología del ámbito productivo". Papers. Revista de Sociologia, 55, 45-77 https://doi.org/10.5565/rev/papers.1932

López-Roldán, P. \& Fachelli, S. (2015). Metodología de la Investigación Social Cuantitativa. Bellaterra (Cerdanyola del Vallès): Dipòsit Digital de Documents, Universitat Autònoma de Barcelona. Edición digital: http://ddd.uab.cat/record/129382

López-Roldán, P. \& Fachelli, S. (2019). Segmentación del empleo y apreciación de la educación en un modelo productivo anclado. Papers. Revista de Sociologia, 104, 2. https://papers.uab.cat/article/download/v104-n2-lopez-fachelli/2571-pdf-es 
López-Roldán, P., Semenza, R., Fachelli, S. \& Sarti, S. (2020). Comparing Labour Market among Spain, Italy, Argentina and Chile. En V. Fortunato (Ed.), Old and New Inequalities in a Globalised World. Experiences from Europe and Latin America. Torino: L'Harmattan, 28-52.

López-Roldán, P., \& Fachelli, S. (2018). A proposal for comparing Labour Market Segmentation: The cases of Spain and Italy. In 39th annual conference of the international working party on labour market segmentation, Trento, 6-7 September

Lopez Roldan, P. \& Fachelli, S. (Eds.) (2021). Towards a Comparative Analysis of Social Inequalities between Europe and Latin America. Springer. Open access._Retrieve from https://link.springer.com/book/10.1007/978-3-030-48442-2

Martín-Artiles, A. (2008). ¿Modelo social de bajo coste? Arxius de Sociologia, 18, 9-24.

Martín Artiles, A.; Chávez Molina, E. \& Semenza, R. (2020). Social models dealing with inequalities. In López-Roldán, Pedro y Fachelli, Sandra (Eds)Towards a Comparative Analysis of Social Inequality between Europe and Latin America. Springer Open access. Retrieve from https://link.springer.com/book/10.1007/978-3-030-48442-2

Maurizio, R. (2016). Non-standard forms of employment in Latin America: Prevalence, characteristics and impacts on wages. Geneva: International Labour Office. http://www.ilo.org/wcmsp5/groups/public/--ed protect/---protrav/---travail/documents/publication/wcms 486160.pdf

Menz, G. (2008). Varieties of capitalism and Europeanisation. Oxford: Oxford University Press.

Miguélez, F. (2004). La flexibilidad laboral. Trabajo, 13, 17-36.

Molina, O. y López-Roldán, P. (2015). "Occupational Growth and Non-Standard Employment in the Spanish Service Sector: from Upgrading to Polarization”. En: W. Eichhorst, Werner y Marx, Paul (eds.). Non-standard employment in a comparative perspective. Cheltenham: Edward Elgar, 110149. https://doi.org/10.4337/9781781001721.00011

Pinto, A. (1970). Naturaleza e implicaciones de la heterogeneidad estructural de América Latina. El trimestre económico, 37(1), 145.

Prebisch, R. (1949). El desarrollo económico de la América Latina y algunos de sus principales problemas. Santiago de Chile: Naciones Unidas.

Recio, A. (1988). Capitalismo y formas de contratación laboral. Madrid: Ministerio de Trabajo y Seguridad Social.

Recio, A. (1991). La segmentación del mercado de trabajo en España. En F. Miguélez \& C. Prieto (Eds), Las relaciones laborales en España (pp. 97-115). Madrid: Siglo XXI.

Rubery, J. (1978). Structured labour markets, worker organisation and low pay. Cambridge Journal of Economics, 2 (1), 17-36. https://doi.org/10.1093/oxfordjournals.cje.a035375

Rubery, J. (2007). Developing segmentation theory: a thirty-year perspective. Économies et Sociétés, 28(6), 941-964.

Rubery, J. (2005). Labor markets and flexibility. In S. Ackroyd, R. Batt, P. Thompson and P. S. Tolbert (Eds), The Oxford Handbook of Work and Organization. Oxford: Oxford University Press, 31-51.

Schneider, B. R. (2009). Hierarchical Market Economies and Varieties of Capitalism in Latin America. Journal of Latin American Studies, Vol. 41, No. 3: 553-575.

Snyder, D.; Kick, E. L. (1979). Structural Position in the World System and Economic Growth, 19551970: A Multiple-Network Analysis of Transnational Interactions. American Journal of Sociology, 84, 5, 1096-1126.

Wilkinson, F (Ed). (1981). The Dynamics of Labour Market Segmentation. London: Academic Press.

Zalakain, J., \& Barragué, B. (2017). Repensar las políticas sociales. Madrid: Grupo 5. 